\title{
1 Community RNA-Seq: Multi-kingdom responses to living versus decaying root inputs in
}

2 soil

4 Erin E. Nuccio ${ }^{1 *}$, Nhu H. Nguyen ${ }^{2}$, Ulisses Nunes da Rocha ${ }^{3}$, Xavier Mayali ${ }^{1}$, Jeremy

5 Bougoure $^{4}$, Peter Weber ${ }^{1}$, Eoin Brodie ${ }^{5,6}$, Mary Firestone $^{5,6}$, Jennifer Pett-Ridge $^{1 *}$

$7 \quad{ }^{1}$ Physical and Life Sciences Directorate, Lawrence Livermore National Laboratory, Livermore,

8 CA, USA; ${ }^{2}$ Department of Tropical Plant and Soil Sciences, University of Hawai'i at Mānoa,

9 Honolulu, HI, USA; ${ }^{3}$ Department of Environmental Microbiology, Helmholtz Centre for

10 Environmental Research, Leipzig, Germany; ${ }^{4}$ Centre for Microscopy, Characterisation \&

11 Analysis, The University of Western Australia, Perth, Australia; ${ }^{5}$ Earth and Environmental

12 Sciences, Lawrence Berkeley National Laboratory, Berkeley, CA, USA; ${ }^{6}$ Department of

13 Environmental Science, Policy and Management, University of California, Berkeley, CA, USA

14

15 Running header: Multi-kingdom responses to detrital root litter

16

17 *Corresponding authors: Erin Nuccio nuccio1@1ln1.gov 925-423-9983, Jennifer Pett-Ridge

18 pettridge2@1lnl.gov 925-424-2882, Lawrence Livermore National Laboratory, Livermore CA, 1994551 USA 


\section{ABSTRACT}

21 Roots are the primary source of organic carbon inputs to most soils. Decomposition is a multi-

22 trophic process involving multiple kingdoms of microbial life, but typically microbial ecology

23 studies focus on one or two major lineages in isolation. We used Illumina shotgun RNA

24 sequencing to conduct PCR-independent SSU rRNA community analysis ("community RNA-

25 Seq") to simultaneously study the bacteria, archaea, fungi, and microfauna surrounding both

26 living and decomposing roots of the annual grass, Avena fatua. Plants were grown in ${ }^{13} \mathrm{CO}_{2}$ -

27 labeled microcosms amended with ${ }^{15} \mathrm{~N}$-root litter. We identified rhizosphere substrate

28 preferences for ${ }^{13} \mathrm{C}$-exudates versus ${ }^{15} \mathrm{~N}$-litter using NanoSIMS microarray imaging (Chip-SIP).

29 When litter was available, rhizosphere and bulk soil had significantly more Amoebozoa, which

30 are potentially important yet often overlooked top-down drivers of detritusphere community

31 dynamics and nutrient cycling. Bulk soil containing litter was depleted in Actinobacteria but had

32 significantly more Bacteroidetes and Proteobacteria. While Actinobacteria were abundant in the

33 rhizosphere, Chip-SIP showed Actinobacteria preferentially incorporated litter relative to root

34 exudates, indicating this group's more prominent role in detritus elemental cycling in the

35 rhizosphere. Our results emphasize that decomposition is a multi-trophic process involving

36 cross-kingdom interactions, and the trajectory of carbon through this soil food web likely

37 impacts the fate of carbon in soil. 


\section{INTRODUCTION}

40 Soil carbon is derived primarily from decomposed plant material $(1,2)$ and the fluxes that

41 control the size of this pool are critical to the global carbon (C) cycle. The soil adjacent to plant

42 roots (the rhizosphere) is a nexus for root $\mathrm{C}$ input, microbial $\mathrm{C}$ transformation, as well as $\mathrm{C}$ loss

43 through decomposition $(3,4)$. Most root $\mathrm{C}$ is decomposed to $\mathrm{CO}_{2}$, and the remainder typically

44 undergoes multiple microbial transformations before it is stabilized. The spatial organization of

45 soil habitats such as the rhizosphere and detritusphere (a region containing non-living organic

46 matter) is particularly important for carbon and nutrient transfer by soil microbes and fauna, and

47 the characteristics and rates of these microbial transformations determine how much carbon

48 remains in soil (5). While it is widely recognized that fungi and soil fauna are instrumental to

49 decomposition (6), less is known about how the greater soil food web of bacteria, archaea, fungi,

50 and microfauna responds to decomposing litter in the rhizosphere and detritusphere.

52 To date, microbial ecology surveys studying litter decomposition using amplicon sequencing

53 have primarily focused on bacteria or fungi, but decomposition is conducted by a broad array of

54 organisms (7) including microfauna (here we use this umbrella term to include protists,

55 nematodes and other soil invertebrates $<100 \mu \mathrm{m})(6,8)$. Fungi play a key role in the

56 decomposition of plant litter by providing the majority of the extracellular enzymes needed to

57 depolymerize plant residues (9) and have been well-studied (10-13). Litter-associated

58 microfauna may consume and directly break down litter (6), and protists and nematodes are also

59 known to consume fungi and bacteria $(8,14-17)$; the presence of these consumers can affect both

60 the microbial community composition and the rate of litter decomposition (18-24). Improving 
61 our understanding of decomposition in soil necessarily requires us to consider the roles and

62 trophic interactions among the broader soil food web.

64 In the past decade, amplicon metabarcoding with high-throughput sequencing approaches have

65 allowed the identification of multiple groups of soil organisms in parallel (25-27). However,

66 PCR amplification has multiple layers of biases, including primer selection and bioinformatic

67 processing, and the lack of a universal primer set means multiple primer sets are required to

68 amplify taxonomically disparate groups (28-30). An alternative approach is to use amplification-

69 independent methods, such as shotgun RNA sequencing (RNA-Seq) for community analysis,

70 which we call "community RNA-Seq". This method not only reduces the inherent biases

71 associated with PCR (31-33), but since rRNA is an integral part of ribosomes that controls

72 protein synthesis across multiple kingdoms of life (34), direct sequencing of RNA allows us to

73 study active communities within Bacteria, Archaea, and Eukarya simultaneously without

74 amplification. Additionally, as most RNA is ribosomal RNA, the resulting sequences have

75 naturally high coverage of the ribosomal subunits most frequently used for taxonomic analysis

76 (e.g., 16S, 18S, 28S) (35), which allows greater sequencing depth of taxonomic markers than

77 metagenomic sequencing. To assess community composition, community RNA-Seq is followed

78 by either reassembling rRNA fragments into full ribosomal subunits or classifying the short

79 reads directly (35-38). Community RNA-Seq has been used to a limited degree in microbial

80 ecology due to the difficulty working with RNA in an environment such as soil, but initial

81 studies suggest it is a particularly useful approach to study protists in soil without PCR and

82 cultivation biases $(35,39)$. Eukaryotic primers are not universal for protists $(40)$, which has led 
83 to Amoebozoa being underrepresented in SSU rRNA gene surveys due to long SSU regions, and

84 ciliates being overrepresented due to short SSU regions (39).

86 Methods that leverage isotopes as tracers of microbial activity (e.g. assimilation of substrates)

87 are capable of adding another layer of ecological information to community analysis studies and

88 have the potential to expand our understanding of food web dynamics and nutrient cycling in

89 multi-trophic communities. Stable isotope probing (SIP) is a suite of powerful methods to study

90 microbial ecophysiology in complex environments $(41,42)$ where a normally rare stable isotope

91 (e.g., ${ }^{13} \mathrm{C},{ }^{15} \mathrm{~N},{ }^{18} \mathrm{O}$ ) is added to the environmental matrix, and organisms that incorporate the

92 labeled substrate become isotopically enriched over time in proportion to their activity $(43,44)$.

93 Nucleic acid-SIP techniques $(43,45)$ are currently the most widely used means to directly

94 connect microbial identity to substrate utilization. An iteration of nucleic acid-SIP is Chip-SIP

95 where an imaging mass spectrometer (NanoSIMS) is used to determine the isotopic enrichment

96 of rRNA hybridized to a phylogenetic microarray $(46,47)$. This method has a low ${ }^{13} \mathrm{C}$

97 enrichment requirement ( 0.5 atom $\%)$ relative to standard SIP, permits shorter isotope

98 incubations, allows dual ${ }^{13} \mathrm{C}$ and ${ }^{15} \mathrm{~N}$ labels in the same sample, and requires no amplification.

99 Using this method, we can trace the fate of ${ }^{13} \mathrm{CO}_{2}$ after it is fixed by plants and released as ${ }^{13} \mathrm{C}$ -

100 rhizodeposits, and simultaneously trace detritus labeled with another isotope (e.g., $\left.{ }^{15} \mathrm{~N}\right)$ to

101 examine the relative incorporation of rhizosphere versus detritus in the same community.

102

103 In this work, we used shotgun RNA sequencing and Chip-SIP to study how living versus detrital

104 root material alters the bacterial, archaeal, fungal, and microfaunal communities in the Avena

105 fatua rhizosphere and surrounding bulk soil. We hypothesized that 1) the detritusphere would 
106 increase saprotrophic fungi and eukaryotic grazers in the rhizosphere, and 2) rhizosphere

107 decomposers would consume both litter and root exudates, rather than specialize on either

108 resource alone.

\section{METHODS}

\section{Microcosm setup and soil collection}

112 Soils were collected at the Hopland Research and Extension Center (HREC, GPS 38.992982, -

113 123.067562) in Hopland, CA (USA), which experiences a Mediterranean climate (48). Soils are

114 a fine loam Alfisol complex (Ultic Haploxeralf mixed with a Mollic Palexeralf) with $1.7 \% \mathrm{C}$ and

$1150.14 \% \mathrm{~N}(49)$. The top $10 \mathrm{~cm}$ of soil was collected from beneath a stand of naturalized Avena

116 barbata within a wild annual grassland community at $1 \mathrm{~m}$ intervals along a $10 \mathrm{~m}$ transect in

117 January. Large plant material was removed, including root pieces, and soil was sieved to $2 \mathrm{~mm}$,

118 homogenized, then mixed with sand (1:1 w/w sand:dry weight soil) to improve drainage. The

119 mixed soil was packed into the main chamber of plastic microcosms $(15 \mathrm{~cm} \times 5 \mathrm{~cm} \times 40 \mathrm{~cm})$ to

120 a density of $1.2 \mathrm{~g} / \mathrm{cm}^{3}$ as previously described (Fig. 1a) (50, 51). Avena fatua seeds (Pacific Coast

121 Seed Inc., Tracy, CA, USA) were germinated in the dark for 7 days. One seedling per microcosm

122 was planted once the roots were greater than $1 \mathrm{~cm}$ long and after the shoot had emerged from the

123 seed. Plants were grown in a greenhouse under a 14-hour photoperiod and watered every 2-3

124 days to field water-holding capacity (approximately 50\% saturation). After 6 weeks, the solid

125 divider separating the main chamber from the sidecar was replaced with a slotted divider (slots

126 ca. $10 \mathrm{~cm} \mathrm{x} 4 \mathrm{~mm}$ ) and the sidecar (5 mm deep) was filled with the experimental soil (Fig. 1a). 
128 Sidecar experimental soil was freshly collected and sieved HREC soil (not mixed with sand), and

129 half of the microcosms received ${ }^{15} \mathrm{~N}$-labeled $A$. fatua root litter chopped to ca. $1 \mathrm{~mm}(78$ atom \%

$130{ }^{15} \mathrm{~N}$; see Supplemental Methods for details regarding production of this material). The ${ }^{15} \mathrm{~N}$

131 isotopic tracer allowed us to use mass spectroscopy to detect the communities that were actively

132 consuming litter-N. For the litter treatment $(n=3)$, the soil was added to the sidecar in two layers,

133 each approximately $2.5 \mathrm{~mm}$ deep: the bottom layer contained $75 \mathrm{~g}$ of soil with no litter, while the

134 top layer contained the $75 \mathrm{~g}$ of soil amended with $0.4 \mathrm{~g}$ of ${ }^{15} \mathrm{~N}$ root litter. For the no-litter control

$135(\mathrm{n}=3), 150 \mathrm{~g}$ of soil was added to the sidecar. After packing the sidecars, microcosms were tilted

136 at $45^{\circ}$ to encourage root growth into the sidecars.

138 After filling the sidecar, plants were grown for 6 days in prior to ${ }^{13} \mathrm{CO}_{2}$ labeling, which is the

139 amount of time it typically takes for roots to enter the sidecar. A $1.5 \mathrm{~m} \times 1.5 \mathrm{~m} \times 0.76 \mathrm{~m}$

140 plexiglass glovebox (Coy Laboratory Products, USA) was used as a labeling chamber at the UC

141 Berkeley EPIC facility (49). The maximum chamber temperature was cycled between $26-28^{\circ} \mathrm{C}$

142 during the day and allowed to cool naturally to $20-22{ }^{\circ} \mathrm{C}$ at night. Before dawn each day, the air

143 in the chamber was cycled through a desiccator filled with soda lime to remove $\mathrm{CO}_{2}$ until the

144 chamber atmosphere reached $<25 \mathrm{ppm} \mathrm{CO}_{2}$. The chamber was then filled with 99 atom $\%{ }^{13} \mathrm{CO}_{2}$

145 until the concentration reached a set point of $400 \mathrm{ppm}$, and maintained at $400 \mathrm{ppm}$ throughout

146 the day using an SBA-5 model IRGA (PP Systems, $400 \mathrm{ppm}{ }^{13} \mathrm{CO}_{2}$ standard calibration) attached

147 to a CR800 model datalogger (Campbell Scientific, Logan, UT, USA). Using this setup, the

148 plants were labeled with ${ }^{13} \mathrm{CO}_{2}$ for 3 days. 
150 After the 3 days of labeling, the front plates of the sidecars were removed to access an intact

151 rhizosphere along the entire length of a root. Rhizosphere soil within $2 \mathrm{~mm}$ of the roots was

152 excised using a scalpel. The soils were immediately placed in ice-cold Lifeguard RNA protectant

153 solution (MoBio). Tubes were shaken for 2 minutes on a horizontal vortex adaptor (MoBio) on

154 medium speed to release soil from the roots. The tubes were centrifuged at $2.5 \times g$ for $1 \mathrm{~min}$ at

$1554^{\circ} \mathrm{C}$, and any roots or floating root litter were removed with flame-sterilized forceps. The

156 remaining soil was pelleted by centrifuging at $2.5 \times \mathrm{g}$ for $5 \mathrm{~min}$ at $4^{\circ} \mathrm{C}$. After the supernatant was

157 carefully removed, the pellets were immediately frozen on dry ice, and stored at $-80^{\circ} \mathrm{C}$ for

158 molecular analysis. Soil $>4 \mathrm{~mm}$ from a root was treated as bulk soil. To collect bulk soils with

159 litter, the top half of the sidecars that contained ${ }^{15} \mathrm{~N}$ labeled litter was randomly excised using a

160 scalpel. These samples often contained visible pieces of ${ }^{15} \mathrm{~N}$ labeled roots. Bulk soil samples

161 were processed in the same manner as rhizosphere soils. We collected a total of 12 soil samples:

1622 locations (rhizosphere, bulk) $\times 2$ litter conditions (litter, no litter) $\times 3$ replicate microcosms.

163 Hereafter, we refer to samples from the unamended control as "rhizosphere" and "bulk" and

164 samples from the litter addition treatment as "rhizosphere-litter" and "bulk-litter".

165

166 RNA Extraction and Sequencing

167 RNA was extracted in triplicate from $0.2 \mathrm{~g}$ soil per sample using the phenol-chloroform

168 extraction protocol (52), modified from (53). Extracted nucleic acids were passed through the

169 Allprep DNA/RNA Mini Kit (Qiagen Sciences, Maryland, USA) to separate RNA from DNA.

170 RNA was treated with DNase using an on-column DNase digestion. For community RNA-Seq,

171 metatranscriptomic libraries were prepared directly from total RNA without rRNA removal

172 using the TruSeq RNA Kit (Illumina, Inc., San Diego, CA, USA) according to the 
173 manufacturer's instructions. Metratranscriptomic libraries were sequenced on an Illumina GAIIX

174 sequencer using 150 basepair (bp) paired-end sequencing at Lawrence Berkeley National

175 Laboratory with an average of 9.5 million paired reads per sample.

176

177 Sequence quality control and rRNA reconstruction

178 Sequences were demultiplexed, and sequence quality was checked with FastQC (54). We used

179 Trimmomatic (55) with default parameters with one exception; we removed the first $10 \mathrm{bp}$ from

180 the 5 ' end due to overrepresentation of this region in the dataset. Sequences shorter than $60 \mathrm{bp}$

181 after trimming were removed. Reads that did not pair were discarded.

182

183 EMIRGE (36) was used to reconstruct near-full-length SSU rRNA sequences for Bacteria,

184 Archaea, and Eukarya using the script “emirge_amplicon.py”. The script was run on paired-end

185 reads with the following parameters: mean insert length of 342, insert standard deviation of 100,

186 and max read length of 151 . The Greengenes 13_5 database clustered at 97\% similarity was used

187 to create the reference database for Bacteria and Archaea (56). The SILVA 114 NR database (57)

188 was used to create the reference database for Eukarya. The database was also clustered at $97 \%$ as

189 above. After the databases were created, the non-standard characters were altered as previously

190 described (36). Bowtie indices required by EMIRGE were calculated for the databases using

191 bowtie-build (58).

192

\section{OTU clustering and classification}

194 Bacterial and archaeal sequences were analyzed separately from eukaryotic sequences.

195 Sequences were clustered using UPARSE (usearch_v7) (59) and analyzed using QIIME 1.8 (60) 
196 at 97\% sequence similarity. OTUs were classified using the RDP classifier (61), where bacterial

197 and archaeal classifications were trained using Greengenes 13_5 and eukaryotic sequences were

198 trained using SILVA 119NR (57). UCHIME (62) was selected to detect chimeras after testing

199 three chimera-checking tools (see Supplemental Methods). OTUs were required to be present in

200 at least two samples, and OTUs classified as chimeras or plant and algal chloroplasts were

201 removed from the dataset. In total, we analyzed 7229 unique full-length bacterial and archaeal

202 RNA sequences created by EMIRGE (1127 OTUs at the 97\% similarity level), and 8488 unique

203 full-length eukaryotic RNA sequences created by EMIRGE (265 OTUs at 97\% similarity level).

205 Since EMIRGE calculates a relative abundance estimate for each consensus sequence, a custom

206 OTU table (sample $\times$ OTU matrix) was created after OTU picking to incorporate relative

207 abundances of the consensus sequences into the microbial community analysis. To convert the

208 consensus sequence relative abundance into sequence abundance, we multiplied the total number

209 of reads that Bowtie mapped to the database by the relative abundance derived from the

210 "normalized priors", as per Miller, Handley (63): total mapped reads $\times$ consensus sequence

211 relative abundance $=$ number of sequences per consensus sequence. Since each OTU can contain

212 multiple consensus sequences, we calculated the OTU sequence abundance by summing the

213 number of sequences for each consensus sequence within the OTU. The samples were then

214 rarefied to an even depth of 121737 sequences for bacteria and archaea, and 27668 sequences

215 for eukaryotes. As per the recommendations of Miller, Handley (63), OTUs with less than $0.01 \%$

216 relative abundance were removed.

\section{Statistical Analysis}


219 Community differences were visualized by Principal Components Analysis (PCA) in QIIME

220 using a pairwise weighted Unifrac distance matrix (64). To determine which OTUs differed in

221 relative abundance between the litter and unamended treatments, we performed two sets of

222 parametric t-tests in QIIME (group_significance.py): rhizosphere vs. rhizosphere-litter; bulk vs.

223 bulk-litter. Only OTUs that were detected in all three replicates of at least one treatment were

224 considered for analysis. P-values were corrected for multiple comparisons using an FDR

225 correction. To calculate kingdom- or phylum-level relative abundances, relative abundances

226 were summed for all OTUs within each group (kingdom for Eukarya, phyla for Bacteria and

227 Archaea) and significant differences were determined using a t-test. Changes in the relative

228 abundances for each group were determined by comparing litter-amended samples to their

229 unamended control for bulk and rhizosphere soil separately (i.e., bulk vs. bulk-litter; rhizosphere

230 vs. rhizosphere-litter).

232 Chip-SIP Analysis

233 To follow the movement of $\mathrm{C}$ and $\mathrm{N}$ from living plants and dead roots into the microbial

234 community, we analyzed the rhizosphere of a microcosm containing both ${ }^{15} \mathrm{~N}$ litter and ${ }^{13} \mathrm{C}$

235 exudates using Chip-SIP, a method that can detect and quantify ${ }^{15} \mathrm{~N} /{ }^{14} \mathrm{~N}$ and ${ }^{13} \mathrm{C} /{ }^{12} \mathrm{C}$ ratios of

236 labeled RNA hybridized to microarrays $(46,47)$. Detailed methods for probe design, microarray

237 synthesis and hybridization, NanoSIMS analysis, and data processing can be found in the

238 Supplemental Methods. Briefly, we designed a microarray with probes using ARB (65) for the

239180 most abundant Bacteria, Archaea, and Eukarya (fungi, protists, nematodes) OTUs found in

240 this study, as well as probes targeting plant chloroplasts; a taxonomy summary of the probes

241 used in this study is available in Table S1. Ten distinct probes per OTU were printed in three 
242 replicate blocks on the microarray. We produced 2 microarrays for this sample, one to detect

243 RNA binding, and a second to detect RNA ${ }^{13} \mathrm{C}$ and ${ }^{15} \mathrm{~N}$ isotopic enrichment with NanoSIMS. To

244 detect RNA binding, RNA was labeled with Alexafluor 532 dye using the Ulysis kit (Invitrogen),

245 fragmented with fragmentation buffer (Affymetrix), purified, concentrated and hybridized onto

246 the first array. For NanoSIMS analysis, unlabeled RNA was again fragmented, purified and

247 concentrated and then hybridized to the second array. The array with fluorescently labeled RNA

248 was imaged with a Genepix 4000B fluorescence scanner. The second array (with non-

249 fluorescently labeled RNA) was also imaged with the fluorescence scanner to allow navigation

250 to analysis spots in the NanoSIMS. Data were collected on the LLNL NanoSIMS 50 in pulse

251 counting mode using aperture slit 3 and entrance slit 5, first collecting ${ }^{12} \mathrm{C}^{14} \mathrm{~N}^{-}$and ${ }^{12} \mathrm{C}^{15} \mathrm{~N}^{-}$, and

252 then ${ }^{12} \mathrm{C}^{14} \mathrm{~N}^{-}$and ${ }^{13} \mathrm{C}^{14} \mathrm{~N}^{-}$. The resulting data were visualized as a stitched isotope map (Fig. S1)

253 and data extracted as per Mayali, Weber (46).

255 The proportion of isotopes is presented as a relative atom percent excess (APE) enrichment ratio 256 of ${ }^{13} \mathrm{C}$ to ${ }^{15} \mathrm{~N}\left({ }^{13} \mathrm{C}-\mathrm{APE}:{ }^{15} \mathrm{~N}-\mathrm{APE}\right)$ to indicate substrate preferences, where lower values indicate 257 greater ${ }^{15} \mathrm{~N}$ enrichment in the RNA, and higher values indicate greater ${ }^{13} \mathrm{C}$ enrichment in the

258 RNA. Due to the higher background of ${ }^{13} \mathrm{C}$ compared to ${ }^{15} \mathrm{~N}$ on the array, we used a

259 normalization factor of 1.7 to calculate these relative enrichment ratios, as previously described

260 (66). Higher relative enrichment in ${ }^{15} \mathrm{~N}$ is interpreted as having a preference for amended ${ }^{15} \mathrm{~N}$

261 root litter whereas higher relative enrichment in ${ }^{13} \mathrm{C}$ is interpreted as having a preference for ${ }^{13} \mathrm{C}$

262 root exudates. We note that this is a relative measure as the ${ }^{13} \mathrm{C}$ values do not reflect the total ${ }^{13} \mathrm{C}$

263 ingested, as part of the ${ }^{13} \mathrm{C}$ consumed is lost through respiration (66). 


\section{RESULTS}

\section{Community Structure from Reconstructed SSU rRNA}

267 The addition of root litter and the presence of living roots both significantly altered the bacterial

268 and eukaryotic communities relative to bulk soil; both the bacterial and eukaryotic communities

269 had significantly different clusters per treatment by PERMANOVA analysis (Fig. 2) (see Table

270 S2 for F Tables), though the eukaryotic communities had more overlap (Fig. 2b). The bulk-litter

271 communities were the most distinct group in ordination space for both bacteria and eukaryotes.

272 Root litter had the strongest effect on both the bacterial and eukaryotic communities, explaining

$27330 \%$ and $28 \%$ of the variance in those communities, respectively (2-way PERMANOVA:

274 bacteria $F_{1,4}=7.2, r^{2}=0.30, p>0.001$; eukaryotes $\left.F_{1,4}=5.4, r^{2}=0.28, p>0.001\right)$. The presence

275 of a living root also significantly altered these communities, which was strongly significant for

276 bacteria (2-way PERMANOVA: $\mathrm{F}_{1,4}=4.7, \mathrm{r}^{2}=0.20, \mathrm{p}=0.006$ ), and was slight but significant for

277 eukaryotes (2-way PERMANOVA: $\left.\mathrm{F}_{1,4}=3.2, \mathrm{r}^{2}=0.17, \mathrm{p}=0.029\right)$.

\section{Phylum and Kingdom Level Responses}

280 We observed broad patterns in relative abundance of bacteria and eukaryotes at the phylum and

281 kingdom level, respectively. Proteobacteria and Actinobacteria were the most abundant bacterial

282 groups in the rhizosphere (Fig. 3a). Actinobacteria, Acidobacteria, and Chloroflexi were

283 significantly reduced in the bulk-litter treatment (t-test: $\mathrm{p}<0.05$ ) (Fig. 3a), while Bacteroides

284 and Proteobacteria were significantly more abundant in the bulk-litter treatment. For the

285 eukaryotes, Amoebozoa were significantly more abundant in presence of litter in both

286 rhizosphere and bulk soils compared to their respective unamended controls (Fig. 3b). In

287 unamended bulk soil, Rhizaria were significantly more abundant. While the litter-containing 
treatments appear to have less Fungi, these differences were not significant $(\mathrm{p}>0.5)$ compared to

289 the unamended controls.

291 Significant Litter and Rhizosphere Responders

292 We compared litter-amended soil to the unamended control for bulk soil and the rhizosphere

293 (Fig. 4). In bulk soil, litter additions significantly increased specific groups of protists, fungi, and

294 bacteria, whereas litter amendments in the rhizosphere had fewer significant responders. Protists

295 from multiple lineages were more abundant in the presence of litter (Fig. 4b), where Colpoda sp.

296 (Alveolata), Glaseria sp. (Amoebozoa), and Naegleria sp. (Heterolobosea) were some of the

297 most abundant genera (Fig. 4b). Platyophyra sp. (Alveolata) were abundant in the rhizosphere

298 and bulk soil when litter was present. Fungal saprotrophic Chaetomium sp. (Ascomycota)

299 responded the most strongly to litter, while the other fungal taxa were more abundant in the

300 absence of litter (Cryptococcus sp., Davidiella sp.). The bacterial taxa that strongly responded to

301 the litter were Massilia sp. in the Oxalobacteriaceae (Proteobacteria), and OTUs in the families

302 Paenibacilliaceae (Firmicutes), and Sphingobacteriaceae (Bacteroidetes) (Fig. 4a). When the

303 rhizosphere was amended with litter, only bacteria in the family Sphingobacteriaceae

304 (Bacteroidetes) significantly increased. Detailed taxonomic results can be found in Table S3.

306 When no litter was present, an unclassified fungus in the phylum Basidiomycota and

307 Platyophrya sp. (Alveolata) responded strongly to the rhizosphere. Protists from the Rhizaria,

308 (phylum Cercozoa) were more abundant in unamended soil, particularly unclassified genera

309 within the classes Thicofilosea and Eugliphida. Taxa that were more prominent in unamended 
310 bulk soil were from the Rhodospirillaceae (Proteobacteria), Bacillaceae (Firmicutes),

311 Solirubrobacterales (Actinobacteria).

\section{Chip-SIP: Substrate Preferences}

314 We used Chip-SIP stable isotope analysis to distinguish substrate preferences in bacterial,

315 archaeal, and eukaryal taxa between root exudates $\left({ }^{13} \mathrm{C}\right.$ enriched) and decaying root litter $\left({ }^{15} \mathrm{~N}\right.$

316 enriched). In the ${ }^{13} \mathrm{C}$-labeled rhizosphere sample amended with ${ }^{15} \mathrm{~N}$-litter, we detected 42

317 isotopically enriched OTUs with Chip-SIP (Fig. 5; 1 archaea, 33 bacteria, 8 fungi); protists

318 probes were on the array but were not enriched during this 3-day ${ }^{13} \mathrm{CO}_{2}$ experiment (see probe

319 taxonomy in Table S1). No microorganism's RNA was enriched solely in ${ }^{13} \mathrm{C}$ or ${ }^{15} \mathrm{~N}$, and only

320 the plant probes on the array were solely enriched with ${ }^{13} \mathrm{C}$ and had the highest relative

321 enrichment ratios of the dataset (Table S4). As a phylum, the Actinobacteria OTUs contained a

322 relatively higher proportion of ${ }^{15} \mathrm{~N}$ than ${ }^{13} \mathrm{C}$ : 6 of 7 enriched taxa fell on the lower range of the

$323{ }^{13} \mathrm{C} /{ }^{15} \mathrm{~N}$ spectrum $(0.2-0.8)$. Xanthobacteriaceae bacteria, Sphingomonas bacteria, and

324 Eurotiomycetes fungi were also more enriched in ${ }^{15} \mathrm{~N}$ relative to the other Chip-SIP taxa (Table

325 S4), however RNA of Sphingomonas sp. and Eurotiomycetes were also equally or more enriched

326 in ${ }^{13} \mathrm{C}$, suggesting that these organisms consumed both fresh and detrital plant material during

327 this 3-day study. Organisms with preference for rhizosphere exudates were 2 Bacillus OTUs, 2

328 Rhizobiales OTUs (Bradyrhizobiaceae, Rhizobium), and 2 Burkholderiales OTUs (Massilia).

329 Fungi from the Ascomycota (Dothideomycetes, Eurotiomycetes, Leotiomycetes) and

330 Basidiomycota (Agaricomycetes) tended to be equally or slightly more relatively enriched in ${ }^{13} \mathrm{C}$

331 than ${ }^{15} \mathrm{~N}$. 


\section{DISCUSSION}

334 While it is widely recognized that fungi and soil fauna are instrumental to decomposition (6),

335 less is known about how decomposition processes interact with the greater soil food web, which

336 includes bacteria, archaea, fungi, and microfauna. To this end, we directly sequenced total RNA

337 to identify bacteria, archaea, and eukaryotes in the presence and absence of root litter, and

338 determined how the presence of a living root altered these communities. We also used

339 NanoSIMS-enabled microarray analysis (Chip-SIP) to track the fate of ${ }^{15} \mathrm{~N}$ root litter and ${ }^{13} \mathrm{C}$

340 rhizodeposits and identified the substrate preferences of abundant organisms in the rhizosphere

341 amended with litter.

343 Protists were abundant in decomposing litter and are important for nutrient cycling

344 We found that protists were abundant in decomposing litter in the presence and absence of living

345 roots. In soil, decomposition is carried out by bacteria, fungi, mesofauna (e.g.

346 microinvertebrates), and macrofauna (e.g. earthworms, millipedes), whose shredding action

347 create smaller particles that are more readily accessible to microbes (6). On the other hand, soil

348 microfauna (e.g. protists, nematodes) primarily consume bacteria and fungi (67-69). Those that

349 feed directly on soil bacteria and fungi are thought to indirectly influence the decomposition of

350 soil organic matter in multiple ways. For example, not only can microfauna alter the composition

351 of bacterial and fungal decomposers, they can also accelerate the turnover of microbial biomass

352 and excrete nutrients derived from microphagy $(12,70)$, which in turn can enhance litter

353 decomposition (24). Protists can stimulate microbial nutrient cycling through the microbial loop

354 (71,72), which is a phenomenon where $\mathrm{N}$ contained in microbial biomass is higher than the $\mathrm{N}$

355 demand of protists, and predation ultimately leads to an increase in available $\mathrm{N}$ after excretion. 
356 The high abundance of protists we observed in decomposing litter may have altered the flow of

357 nutrients though grazing and is an important dynamic currently missed in many bacterial and

358 fungal litter decomposition studies.

Amoebas are potentially important yet overlooked top-down driver of detritusphere community

\section{1 dynamics and nutrient cycling}

362 Rhizaria (Cercozoa), Amoebozoa, and Alveolata were the most abundant protists in our soils. A

363 previous metatranscriptomic study also found that Rhizaria and Amoebozoa were abundant in

364 grassland soils relative to peatlands (39). Interestingly, we predominantly observed Rhizaria in

365 unamended bulk soil, whereas Amoebozoa were more abundant when litter was present in both

366 bulk soil and the rhizosphere. This suggests these two abundant groups inhabit different niches

367 within the soil environment. In a complementary transcriptomics dataset from this soil (52),

368 Amoebozoa expression of exoproteases was highest in the litter-containing rhizosphere and bulk

369 soils (Figure S2), which further suggest these organisms play an active role in microbial

370 community dynamics in the detritusphere. Microfaunal predation is generally overlooked as a

371 top-down driver of microbial community assembly (73). Amoebas in particular are known to be

372 mycophagous or bacterivores $(15,16)$ and can influence microbial community structure (12). As

373 the Amoebozoa Supergroup is typically missed in amplicon analysis (74), our results suggest

374 Amoebas may be an overlooked contributor to microbial community dynamics and nutrient

375 cycling in the detritusphere.

377 Rhizosphere and bulk soil harbor unique litter-decomposing communities 
378 Each treatment in this study had a unique microbial community, where the rhizosphere and bulk

379 soil contained distinct assemblages of potential decomposers. In particular, the bulk-litter

380 community had significantly more Bacteroidetes, Proteobacteria (Oxalobacteriaceae,

381 Caulobacteraceae, Bacteriovoraceae), and saprotrophic Chaetomium fungi relative to the

382 unamended control, but was depleted in Actinobacteria and Acidobacteria. In the rhizosphere,

383 both sequencing and ${ }^{15} \mathrm{~N}$-litter Chip-SIP identified members of the Sphingobacteriaceae as

384 responders to litter; Chip-SIP also identified Xanthobacteriaceae bacteria and Eurotiomycetes

385 fungi as consumers of ${ }^{15} \mathrm{~N}$-litter in the rhizosphere. Previous stable isotope probing studies have

386 identified taxa from the Actinobacteria, Firmicutes, and Bacteroidetes as bacterial decomposers

387 of plant material in soil $(75,76)$, and taxa from the Burkholderiales, Caulobacteriales,

388 Rhizobiales, Sphingobacteriales and Xanthomonadales as cellulose-degrading bacteria (77). The

389 low abundance of Actinobacteria in the bulk-litter soil was unexpected given that they are

390 commonly identified as soil decomposers (75-77), and the trend toward reduced total fungi

391 transcripts (Fig. 4b) did not support our initial hypothesis. In bulk-litter soil, a different suite of

392 decomposers may have preferred the root litter in our system (e.g., Bacteroidetes, Chaetomium

393 fungi) instead of Actinobacteria. Alternatively, the reduction in Actinobacteria and trend toward

394 reduced total fungi in the presence of litter might be explained by interactions among soil

395 microbes. As Amoebozoa and bacterial predators (e.g., Bacteriovoraceae) were abundant in the

396 litter-containing treatments, it is possible that the low abundance of common decomposers in the

397 presence of litter might have been driven by fungal or bacterial grazing $(78,79)$. Members of the

398 Oxalobacteriaceae have also been shown to consume fungi (80), though we did not identify any

399 known mycophageous genera in our dataset. We also note that we did not observe any

400 macrofauna or mesofauna sequences in the dataset; macrofauna (and possibly mesofauna) would 
401 have been removed during the processing phase of soils, or because the amount of soil extracted

402 for DNA was too small in volume.

404 Isotopic tracers identify substrate preferences in the rhizosphere

405 The Chip-SIP results helped us to start to disentangle microbial substrate preferences in the

406 rhizosphere. We used two isotopic tracers to determine if soil microbes preferentially consumed

$407{ }^{13} \mathrm{C}$-exudates or ${ }^{15} \mathrm{~N}$-litter. In the rhizosphere-litter treatment, the Actinobacteria tended to prefer

$408{ }^{15} \mathrm{~N}$-litter, while Fungi and the Rhizobiales tended to assimilate ${ }^{15} \mathrm{~N}$-litter and ${ }^{13} \mathrm{C}$-exudates

409 equally, with a slight preference for ${ }^{13} \mathrm{C}$-exudates. While Actinobacteria were the second-most

410 abundant phylum in the rhizosphere treatments, the Chip-SIP data indicated that they may have

411 preferred to consume detrital SOM in this habitat; this is consistent with recent findings where

412 the Actinobacteria had the highest CAZyme gene expression in the detritusphere or aging

413 rhizosphere (rhizosphere $>20$ days old) (52). Actinobacteria have been identified as plant- or

414 cellulose-degraders by density gradient SIP (75-77). This highlights that 16S patterns alone have

415 a limited ability to determine substrate preferences and require additional information to assess

416 microbial ecophysiology, such as through isotope tracing or activity-based analyses.

\section{Relevance of the microbial food web for soil C cycling}

419 The multi-trophic changes we observed in our study are relevant for soil carbon cycling.

420 Microbial communities have diverse arrays of physiological strategies for consuming carbon

421 substrates (7). Changes in the microbial community can influence the rate of decomposition and

422 decomposition products $(7,81)$, and are expected to alter the diversity of compounds available

423 for sorption to mineral surfaces (82). For example, we found that Actinobacteria decreased in the 
424 bulk-litter treatment while Chaetomium fungi increased, which likely altered the composition of

425 exoenzymes available to breakdown plant material and can further influence the rates and types

426 of organic matter that can be degraded $(83,84)$. Microbial bodies themselves define the forms of

427 C available for stabilization, such as cell wall components, polysaccharides, enzymes,

428 intracellular sugars, and intermediate products of litter decomposition $(7,83,85-87)$; these

429 components can have different residence times in soil $(83,88)$. Selective predation, such as by

430 protists or Bacteriovoraceae, can alter the both the taxonomic and functional composition of the

431 soil microbiome (73). In addition, predation by protists potentially diversifies and alters forms of

$432 \mathrm{C}$ available for sorption to mineral surfaces since the microbial polymers undergo digestion

433 before excretion, and protists have been shown to selectively retain particular classes of

434 metabolites (89). Thus, the trajectory of carbon through the soil food web likely impacts the fate

435 and persistence of carbon in soil.

CONCLUSIONS

438 Using metatranscriptomic sequencing of total RNA, we identified the bacterial, archaeal, and

439 eukaryotic communities that responded to detrital root litter in rhizosphere and bulk soil. Litter-

440 decomposing communities differed depending on the presence and absence of a root, where the

441 litter-amended bulk soil had the most distinct microbial and protist communities. The litter-

442 amended rhizosphere and bulk soil contained significantly more Amoebozoa than the

443 unamended controls, and grazing by these protists may be an important top-down control on the

444 microbial community during litter decomposition and alter the trajectory of carbon through the

445 soil food web. Chip-SIP NanoSIMS analysis identified substrate preferences for ${ }^{15} \mathrm{~N}$ root detritus

446 or ${ }^{13} \mathrm{C}$ rhizodeposits fresh root exudates and gave insights into food web processes that were not 
447 discernible from compositional analyses alone. Future work combining shotgun RNA

448 community analyses and stable isotopes has the potential to improve our ability to track nutrients

449 through multi-trophic food webs.

451 ACKNOWLEDGEMENTS

452 This research was supported by the U.S. Department of Energy Office of Science, Office of

453 Biological and Environmental Research Genomic Science program under awards SCW1421,

454 SCW1589, and SCW1678 to JPR and under awards DE-SC0010570, DOE-SC0016247, and DE-

455 SC0020163 to MKF. Work conducted at Lawrence Livermore National Laboratory was

456 supported under the auspices of the U.S. DOE under Contract DE-AC52-07NA27344. Work

457 conducted at Lawrence Berkeley National Laboratory was supported under Contract DE-AC02-

458 05CH11231. We thank Katerina Estera Molina and Shengjing Shi for laboratory assistance,

459 Donald Herman for assistance with the EPIC ${ }^{13} \mathrm{CO}_{2}$ labeling system, Ulas Karaoz for data

460 management assistance, and Ella Sieradzki for the Acanthamoebidae supplemental figure.

462 CONFLICTS OF INTEREST

463 The authors declare no conflicts of interest. 


\section{FIGURES}

466
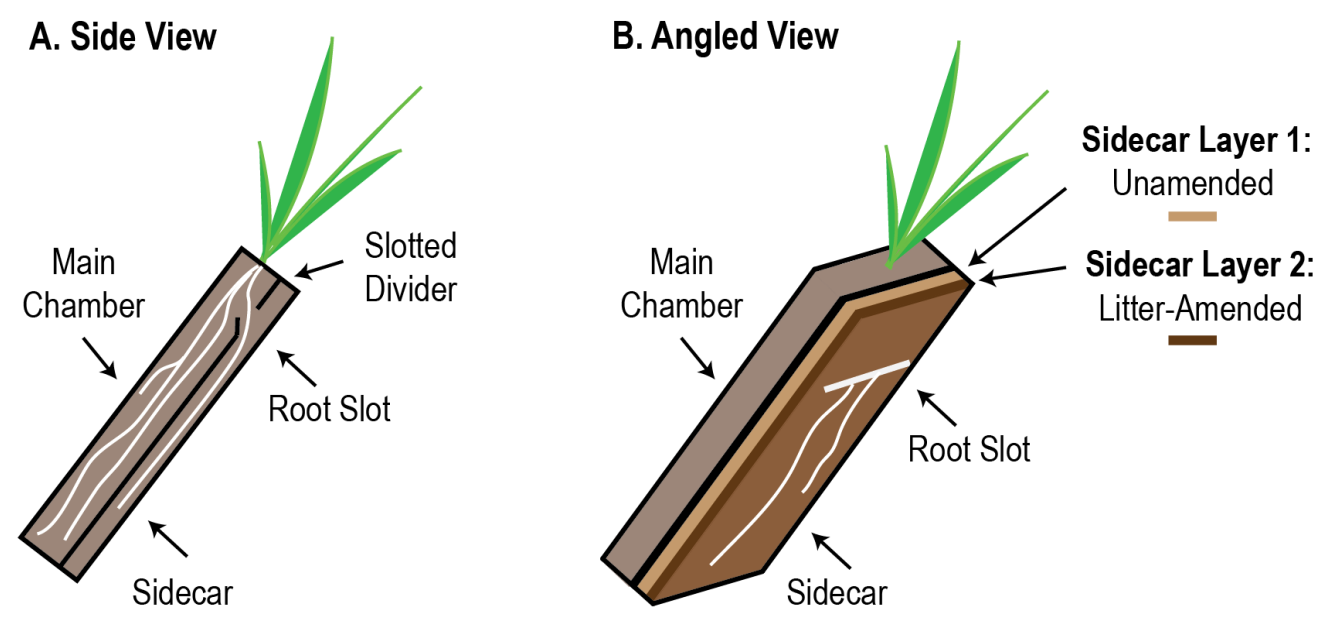

469 Figure 1: Microcosm design and sampling strategy. (A) Microcosms had a main chamber that

470 housed the plant during plant growth and maturation. The main chamber was separated from an

471 auxiliary root chamber (the sidecar) by a solid divider; microcosms were tilted to promote the

472 growth of roots. After 6 weeks, the solid divider was removed and replaced with a slotted divider

473 to permit root growth into the sidecar, and the sidecar was then filled with the experimental soil.

474 (B) Half of the experimental soils were amended with ${ }^{15} \mathrm{~N}$-labeled root detritus (layer 2), which

475 was placed on top of unamended soil (layer 1). Unamended controls were prepared in the same

476 manner, but no litter was added to the second layer. After 6, days the roots entered the sidecar,

477 and the plants were then pulse labeled for 3 days with ${ }^{13} \mathrm{CO}_{2}$ and harvested. Roots grew along the

478 face of the sidecar and rhizosphere soil ( $<2 \mathrm{~mm}$ from root) and bulk soil ( $>4 \mathrm{~mm}$ from root) were

479 excised with a scalpel. 


\section{A. Bacteria and Archaea}

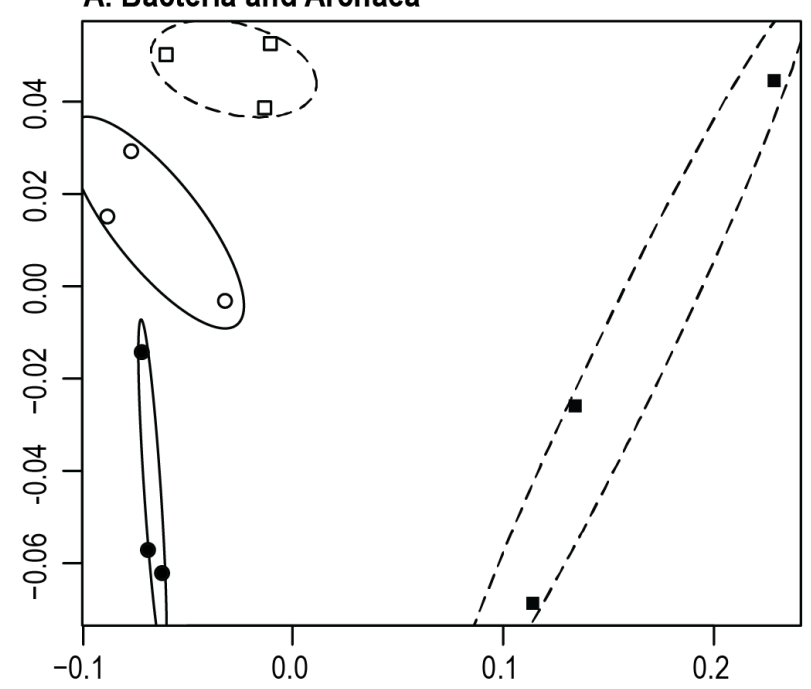

\section{B. Eukarya}

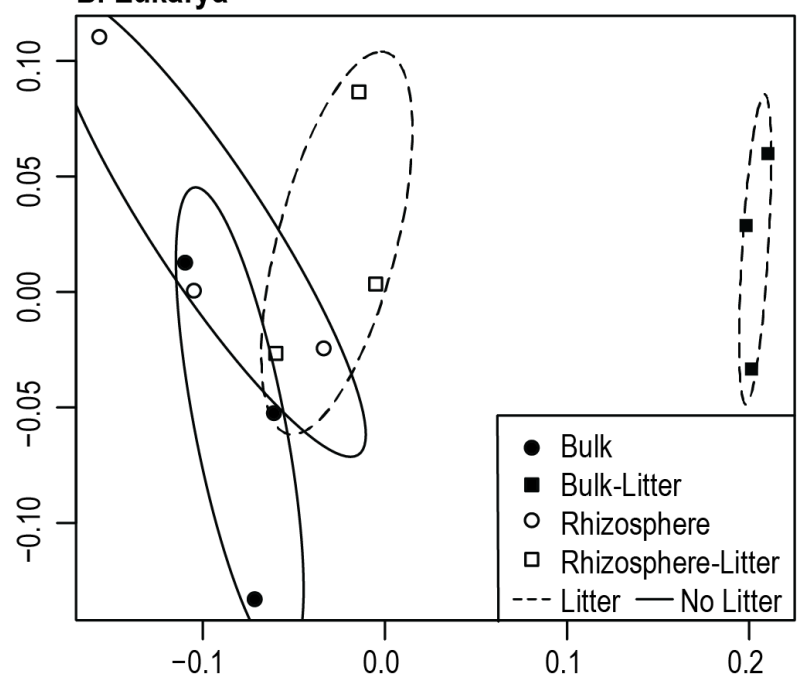

481 Figure 2: Community RNA-Seq non-metric multidimensional scaling ordinations for (A)

482 Bacteria and Archaea (assembled 16S rRNA), and (B) Eukarya (assembled 18S rRNA) in the

483 Avena fatua rhizosphere and bulk soil in response to litter amendments. Soil was sampled after 3

484 days of fresh root growth into the microcosm sidecars. Filled symbols represent bulk soil, while

485 hollow symbols represent rhizosphere soil. Squares indicate litter addition while circles had no

486 litter added. Ovals represent the 95\% standard error of the weighted average of scores per group

487 (r package: ordiellipse) for litter treatments (dashed lines) and no litter (solid lines). 

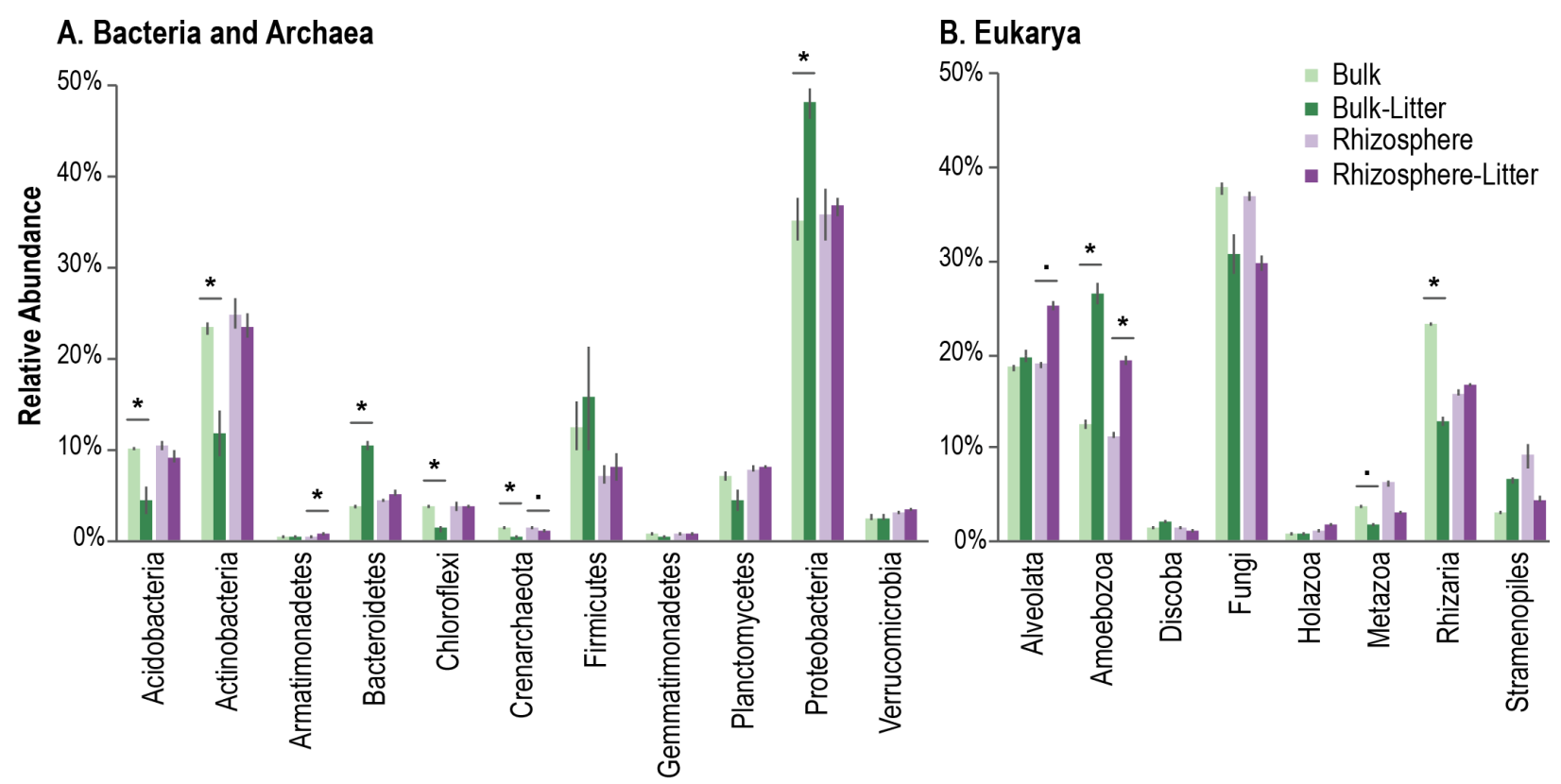

491 Figure 3: SSU rRNA relative abundance at the (A) phyla level for Bacteria and Archaea, and

492 (B) kingdom for Eukarya. The treatments were as follows: bulk soil with no litter amendment

493 (bulk, light green) and amended with root litter (bulk-litter, dark green), and rhizosphere soil

494 with no litter amendment (rhizosphere, light purple) and amended with root litter (rhizosphere-

495 litter, dark purple). Groups that significantly differed in relative abundance with litter

496 amendments are indicated by * (t-test: $\mathrm{p}<0.05)$ (Bulk vs. Bulk-Litter; Rhizosphere vs.

497 Rhizosphere-Litter), and “.” indicates marginal significance $(\mathrm{p}<0.1)$. 
bioRxiv preprint doi: https://doi.org/10.1101/2021.01.12.426429; this version posted January 13, 2021. The copyright holder for this preprint (which was not certified by peer review) is the author/funder. This article is a US Government work. It is not subject to copyright under 17 USC 105 and is also made available for use under a CCO license.

A.

\begin{tabular}{|rr}
\hline Verrucomicrobia & $\begin{array}{r}\text { Unclassified } \\
\text { Verrucomicrobiaceae } \\
\text { Chthoniobacteraceae }\end{array}$ \\
\hline Proteobacteria & Unclassified \\
Xanthomonadaceae
\end{tabular}

Xanthomonadaceae

Sphingomonadaceae

Rhodospirillaceae

Rhizobiaceae

Oxalobacteraceae

Hyphomicrobiaceae

Comamonadaceae

Caulobacteraceae

Bradyrhizobiaceae

Bdellovibrionaceae

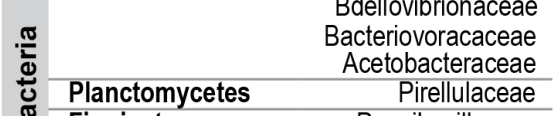

m Firmicutes $\quad \begin{array}{r}\text { Paenibacillaceae } \\ \text { Clostridiaceae }\end{array}$

$\begin{array}{rr}\text { Chloroflexi } & \text { Kacillaceae } \\ \text { FFCH4haceae } & \end{array}$

\begin{tabular}{lr}
\hline Bacteroidetes & $\begin{array}{r}\text { Sphingobacteriaceae } \\
\text { Flexibacteraceae }\end{array}$ \\
\hline Armatimonadetes & $\begin{array}{r}\text { Unclassified } \\
\text { Fimbrimonadaceae }\end{array}$ \\
\hline
\end{tabular}

Actinobacteria Solirubrobacterales

Nocardioidaceae

Micromonosporaceae

Gaiellaceae

EB1017

\begin{tabular}{lr}
\hline Acidobacteria & Unclassified \\
\hline Crenarchaeota & Nitrososphaeraceae
\end{tabular}
No Litter
- Bulk
- Rhizosphere

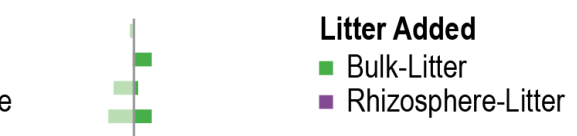
Litter Added
- Rhizosphere-Litter

B. $\backsim$ Chrysophyceae Unclassified

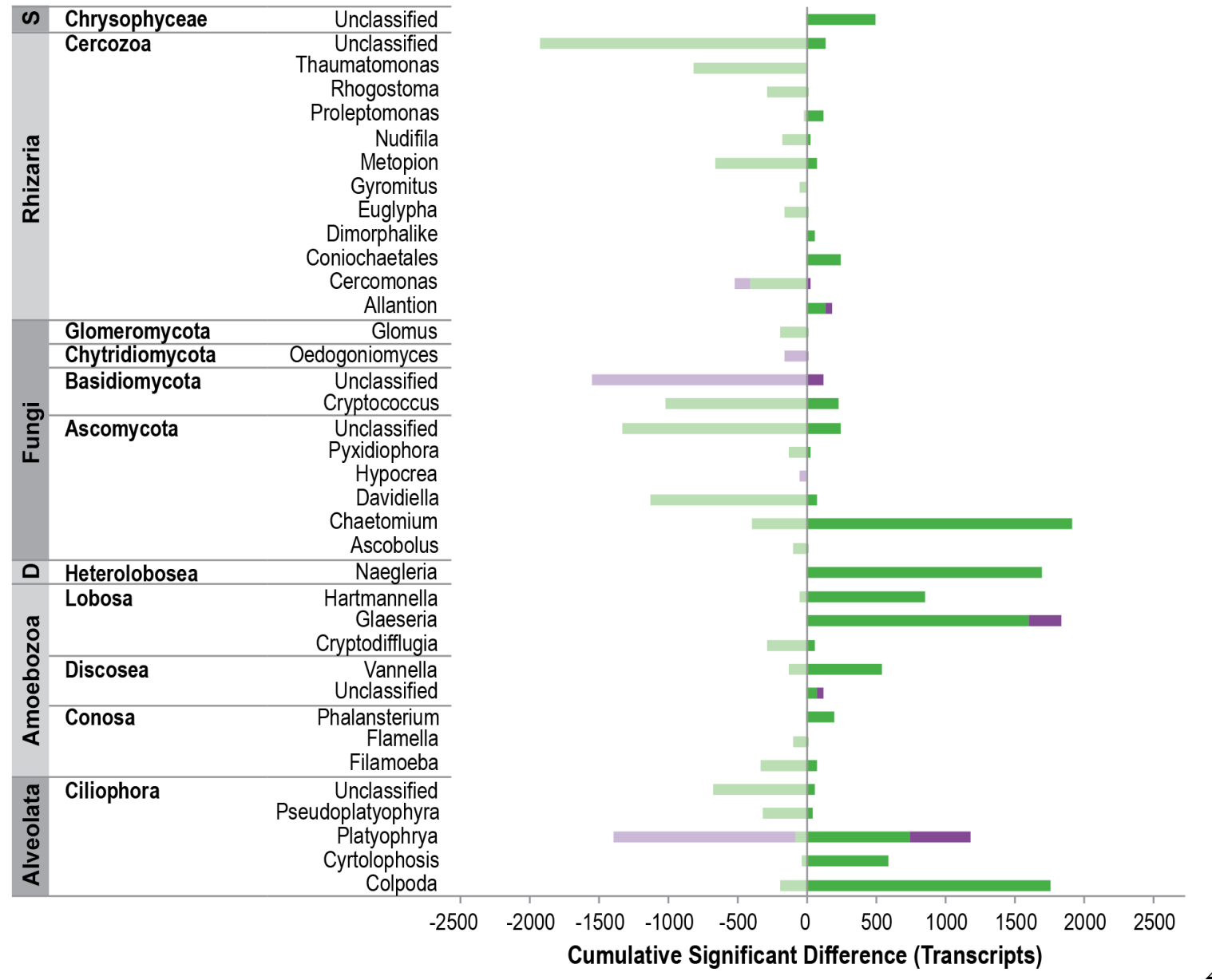


$500 \quad$ Figure 4: Cumulative significantly-different transcripts for positive and negative responders to

501 detrital root litter in bulk soil and the rhizosphere. The effects of litter amendments were

502 calculated separately for bulk soil and rhizosphere soil, where "dark green" indicates cumulative

503 positive responses to litter for bulk soil, and "dark purple" indicates cumulative positive

504 responses to litter for rhizosphere soil. Negative responses to litter (or preference for unamended

505 soil) are "light green" for bulk soil and "light purple" for rhizosphere soil. Transcripts were

506 aggregated by taxonomic family for Bacteria and Archaea and genus for Eukarya; OTU

507 transcript abundances were averaged across replicates $(\mathrm{n}=3)$ prior to aggregation. Multiple

508 comparisons were accounted for using a FDR p-value correction.

509 


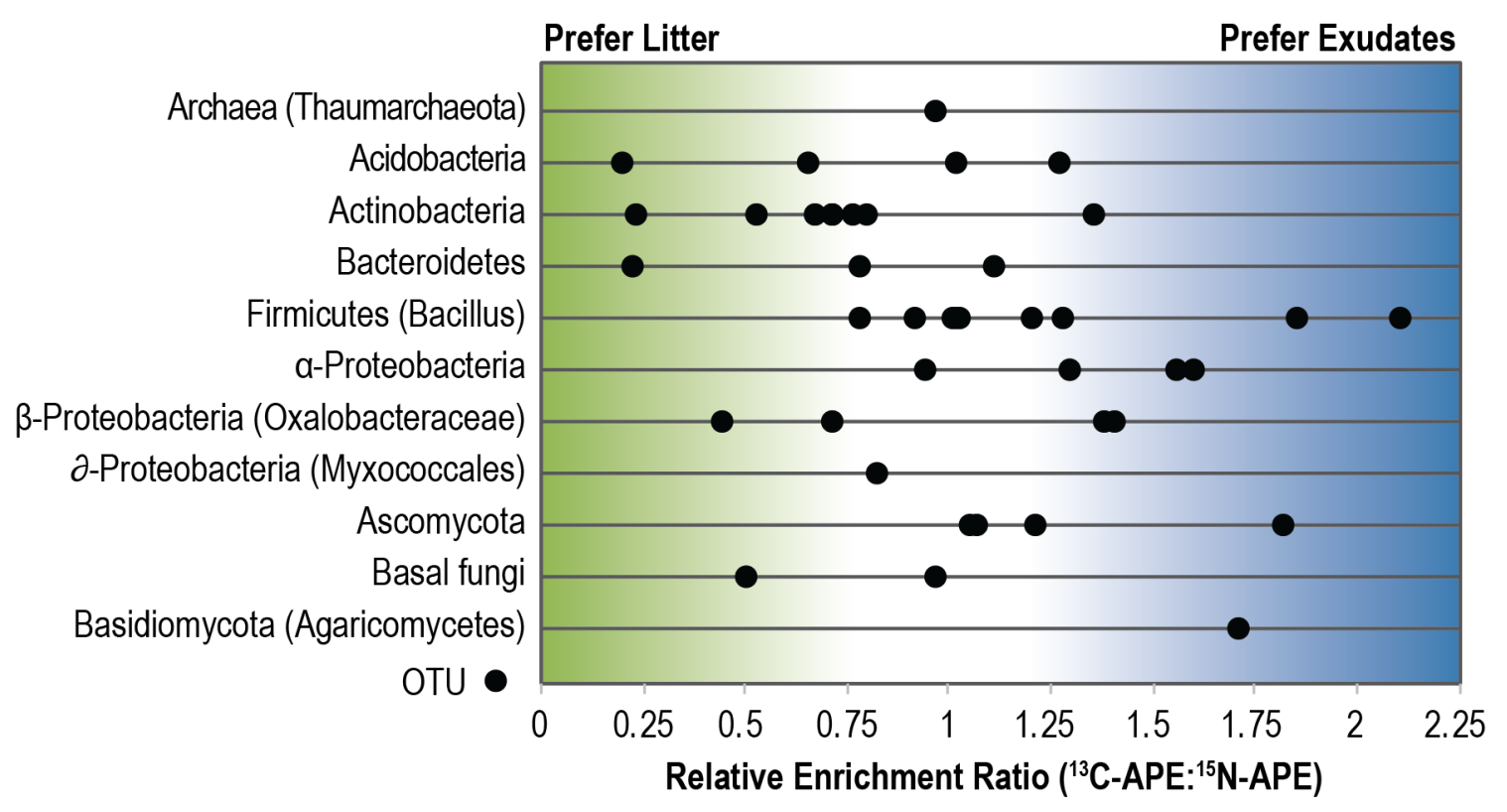

514 Figure 5. Relative substrate preferences for Bacteria, Archaea, and Fungi detected by Chip-SIP.

515 Each dot represents a taxon that was significantly enriched in ${ }^{13} \mathrm{C}$ or ${ }^{15} \mathrm{~N}$ derived from ${ }^{13} \mathrm{C}$ -

516 exudates or ${ }^{15} \mathrm{~N}$-root detritus. The $\mathrm{x}$-axis is the ratio of the atom percent excess (APE) ${ }^{13} \mathrm{C}$

517 enrichment and ${ }^{15} \mathrm{~N}$ enrichment for the probe set, which is a unitless relative measure; the ratio

518 was corrected by 1.7 to account for dilution of the $\mathrm{C}$ signal by the chip surface. The position of

519 the taxon along the $\mathrm{x}$-axis indicates its preference for exudates or root litter. Those that are

520 positioned towards the left (green) incorporated relatively more isotope from ${ }^{15} \mathrm{~N}$-litter whereas

521 those that are positioned towards the right (blue) incorporated relatively more isotope from ${ }^{13} \mathrm{C}$ -

522 exudates. Probes targeting protists and nematodes were on the chip (Table S1) but we did not

523 measure any significant enrichment in this 3-day ${ }^{13} \mathrm{CO}_{2}$ experiment. 


\section{SUPPLEMENTAL}

\section{Production of ${ }^{\mathbf{1 5}} \mathbf{N}$-labeled root litter}

527 To create ${ }^{15} \mathrm{~N}$-labeled root litter, Avena fatua was grown for 8 weeks in fritted clay and fertilized

528 solely with a custom mixture of Hoagland's plant nutrient solution, where the nitrogen-

529 containing compounds were replaced with their 99 atom $\%{ }^{15} \mathrm{~N}$ analogs $\left(0.505 \mathrm{~g} / \mathrm{L} \mathrm{K}{ }^{15} \mathrm{NO}_{3}\right.$

530 (Cambridge Isotope Laboratories), $0.59 \mathrm{~g} / \mathrm{L} \mathrm{Ca}\left({ }^{15} \mathrm{NO}_{3}\right)_{2} \mathrm{x} 4 \mathrm{H}_{2} \mathrm{O}$ (Cambridge Isotope

531 Laboratories), $0.0225 \mathrm{~g} / \mathrm{L}$ Sprint 330 iron chelate (Becker Underwood), $0.493 \mathrm{~g} / \mathrm{L} \mathrm{MgSO} 4 \mathrm{X}$

$5327 \mathrm{H}_{2} \mathrm{O}, 0.080 \mathrm{~g} / \mathrm{L}^{15} \mathrm{NH}_{4}{ }^{15} \mathrm{NO}_{3}$ (Cambridge Isotope Laboratories), $2.86 \mathrm{~g} / \mathrm{L} \mathrm{H}_{3} \mathrm{BO}_{3}, 1.81 \mathrm{~g} / \mathrm{L}$

$533 \mathrm{MnCl}_{2} \times 4 \mathrm{H}_{2} \mathrm{O}, 0.22 \mathrm{~g} / \mathrm{L} \mathrm{ZnSO}_{4} \times 7 \mathrm{H}_{2} \mathrm{O}, 0.051 \mathrm{~g} / \mathrm{L} \mathrm{CuSO} 4,0.09 \mathrm{~g} / \mathrm{L} \mathrm{H}_{3} \mathrm{MoO}_{4} \times \mathrm{H}_{2} \mathrm{O}$, and 0.5

$534 \mathrm{ml} / \mathrm{L}$ of $\left.1 \mathrm{M} \mathrm{KH}_{2} \mathrm{PO}_{4}(\mathrm{pH} 6.0)\right)$. Roots were triple washed in deionized water, dried, and stored

535 for 1 year prior to use. Roots were chopped to ca. $1 \mathrm{~mm}$ lengths using scissors.

\section{Data processing using EMIRGE}

538 Since EMIRGE probabilistically reconstructs sequences, the near full-length sequences have a

539 higher error rate than sequences directly generated by Illumina sequencing. To address this,

540 singletons and sequences present in only one sample were removed from the dataset. Next, we

541 assessed the efficacy of three chimera checking tools to identify potential chimeras created by

542 EMIRGE (UCHIME (62), DECIPHER (90), Chimera Slayer (91)), and determined that

543 UCHIME was the most effective chimera-checking tool for our dataset. To assess the chimera-

544 checking tools, we used a set of EMIRGE sequences reconstructed from a mock community

545 composed of 52 known isolates available as a supplemental dataset from Miller, Baker (36). Any

546 novel sequences in this EMIRGE dataset are likely chimeras, since the SSU sequences of all the

547 community members are known. We determined that 3 of 23 reconstructed sequences were 
548 putative chimeras, since they were $<90 \%$ similar to organisms in the NCBI database using

549 BLAST. We tested each chimera-detection method to determine if it could identify these 3

550 sequences in the EMIRGE dataset. Only UCHIME was capable of detecting chimeras in the

551 dataset; it was able to identify 2 of the 3 putative chimeras. Therefore, UCHIME was used for

552 chimera-checking analyses.

554 Probe design: We designed a custom Chip-SIP array for rhizosphere soil with probes targeting

555 bacteria, archaea, and eukaryotes (fungi, protists, nematodes). Probes were designed from the

556 sequences reconstructed by EMIRGE from the four treatments in this experiment. The 180 most

557 abundant OTU from bacteria, archaea, and eukarya were targeted for probe design. The

558 microarray probes were designed in ARB using the following restrictions: $(\leq 2$ mismatches

559 tolerated, GC content $<80 \%$, homopolymer runs $\leq 4 \mathrm{bp})(65)$. Twenty-five different probes were

560 selected for each sequence that were unique relative to the SILVA database and RNA-Seq

561 databases. Based on preliminary fluorescence data (using soils from actual experiment), from

562 these 25 probes, we selected the 10 probes that had the highest hybridization scores to synthesize

563 on the final microarray (signal:noise $\geq 1.3$ ). Sequences that had few probes with positive

564 fluorescence (signal:noise $<1.3$ ) were added to the microarray by keeping 10 probes with the

565 best ARB score (a measure of how specific the probe is to the sequence of interest).

567 Chip-SIP microarray synthesis: Microarrays were coated with a conductive surface prior to

568 probe synthesis to eliminate charging during SIMS analysis. Glass slides coated with indium-tin

569 oxide (Sigma) were treated with an alkyl phosphonate hydroxy-linker to provide a starting

570 substrate for probe synthesis (92). Microarray probes (spot size $=17 \mu \mathrm{m}$ ) were synthesized using 
571 a photolabile deprotection strategy (93) on a Nimblegen Maskless Array Synthesizer (Roche).

572 The probe sets were laid out in horizontal lines across the chip. All the probes were printed three

573 times in three replicate blocks on the microarray. Nimblegen synthesis reagents (Roche) were

574 delivered through the Expedite system (PerSeptive Biosystems).

576 Microarray hybridization: Two microarrays are necessary for Chip-SIP: a standard

577 fluorescence microarray and a separate NanoSIMS microarray. Fluorescence analysis is

578 necessary to confirm that the probes are hybridized with RNA. However, labeling RNA with a

579 fluorophore introduces ${ }^{12} \mathrm{C}$-carbon that dilutes the ${ }^{13} \mathrm{C}$ signal. Therefore, the RNA samples were

580 split for fluorescence and NanoSIMS analyses and the RNA used in the NanoSIMS analysis was

581 left unlabeled. Microarrays were not replicated.

583 For fluorescence analysis, the RNA was labeled with Alexafluor 532 dye using the Ulysis kit

584 (Invitrogen), and were incubated for $10 \mathrm{~min}$ at $90^{\circ} \mathrm{C}(2 \mu \mathrm{L}$ RNA, $10 \mu \mathrm{L}$ labeling buffer, $2 \mu \mathrm{L}$

585 Alexafluor reagent) and subsequently fragmented. RNA for NanoSIMS analysis was not labeled,

586 and instead preceded directly to fragmentation. Samples were fragmented using 5X

587 fragmentation buffer (Affymetrix) for $10 \mathrm{~min}$ at $90^{\circ} \mathrm{C}$. Fragmented RNA was purified using a

588 Spin-OUT ${ }^{\mathrm{TM}}$ minicolumn (Millipore), and RNA was concentrated by ethanol precipitation to a

589 final concentration of $500 \mathrm{ng} \mu \mathrm{L}^{-1}$. For array hybridization, RNA samples were mixed with $1 \mathrm{X}$

590 Hybridization buffer (Nimblegen) and placed in a Nimblegen X4 mixer slide. The arrays were

591 incubated inside a Maui hybridization system (BioMicro Systems) for $18 \mathrm{hrs}$ at $42^{\circ} \mathrm{C}$ and then

592 washed according to manufacturer's instructions (Nimblegen). 
594 Arrays with fluorescently labeled RNA were imaged with a Genepix 4000B fluorescence scanner

595 at pmt $=650$ units. Arrays with non-fluorescently labeled RNA were marked with a diamond pen

596 and also imaged with the fluorescence scanner to subsequently navigate to the analysis spots in

597 the NanoSIMS. Slides were trimmed and mounted in custom-built stainless-steel holders.

599 Chip-SIP NanoSIMS analyses: Mass resolution was set to $\sim 10,000$ mass resolving power to

600 minimize the contribution of isobaric interferences to the species of interest (e.g., so that ${ }^{11} \mathrm{~B}^{16} \mathrm{O}^{-}$

601 contributes $<1 / 100$ of the ${ }^{13} \mathrm{C}^{14} \mathrm{~N}^{-}$ratio, and ${ }^{13} \mathrm{C}_{2}$ - contributes $<1 / 1000$ of the ${ }^{12} \mathrm{C}^{14} \mathrm{~N}^{-}$ratio).

602 Analyses were performed in imaging mode to generate digital ion images of the microarray for

603 each ion species. The primary beam current was 5 to $7 \mathrm{pA} \mathrm{Cs}^{+}$, which yielded a spatial

604 resolution of $200-400 \mathrm{~nm}$ and a maximum count rate on the detectors of $\sim 300,000 \mathrm{cps}{ }^{12} \mathrm{C}^{14} \mathrm{~N}$.

605 Analysis area was $50 \times 50 \mu \mathrm{m}^{2}$ with a pixel density of $256 \times 256$ with 0.5 or $1 \mathrm{~ms} /$ pixel dwell

606 time. Ion counts were corrected for detector dead time on a pixel-by-pixel basis.

608 Chip-SIP statistical analyses: Individual $50 \times 50 \mu \mathrm{m}^{2}$ isotope ratio images were stitched

609 together to create an isotope map of the microarray surface using custom software developed for

610 NanoSIMS analysis (L'image, L. Nittler, Carnegie Institution of Washington). Probe spot

611 regions of interest (ROIs) were selected by hand or with an autodefinition function, and ${ }^{15} \mathrm{~N} /{ }^{14} \mathrm{~N}$

612 and ${ }^{13} \mathrm{C} /{ }^{12} \mathrm{C}$ isotope ratios were calculated for each ROI. Isotope ratios were converted to atom

613 percent excess (APE) values using the formula APE $=\left[R_{\text {meas }} /\left(1+R_{\text {meas }}\right)-R_{\text {control }} /\left(1+R_{\text {control }}\right)\right] \times$

$614100 \%$, where $R_{\text {meas }}$ is the isotope ratio measured by NanoSIMS and $R_{\text {control }}$ is the mean ${ }^{15} \mathrm{~N}$ APE

615 or ${ }^{13} \mathrm{C}$ APE value for the control probe locations. The presence of RNA on each probe was 
616 confirmed using a separate fluorescence microarray analysis, where hybridized probes had a

$617 \quad$ signal to noise ratio $>1.3$.

618

619 Two criteria identified which OTUs were enriched with ${ }^{13} \mathrm{C}$ or ${ }^{15} \mathrm{~N}$. First, each probe set was

620 required to have five of ten probes with a signal:noise ratio $>1.3$; this determined which OTUs

621 were present in the dataset. Second, each probe set had to have five probes with enrichment of

622 either $>0.020{ }^{13} \mathrm{C}$ atom percent excess (APE) or $>0.011{ }^{15} \mathrm{~N}$ APE (equivalent to $30 \%$ for both).

623 For the OTUs that met these criteria, we calculated a ${ }^{13} \mathrm{C}-\mathrm{APE}:{ }^{15} \mathrm{~N}-\mathrm{APE}$ ratio for the entire probe

624 set by averaging all APE enrichments $>0$ for ${ }^{13} \mathrm{C}$ and ${ }^{15} \mathrm{~N}$ and then dividing the two averages

625 (average ${ }^{13} \mathrm{C}$ APE / average ${ }^{15} \mathrm{~N}$ APE). 

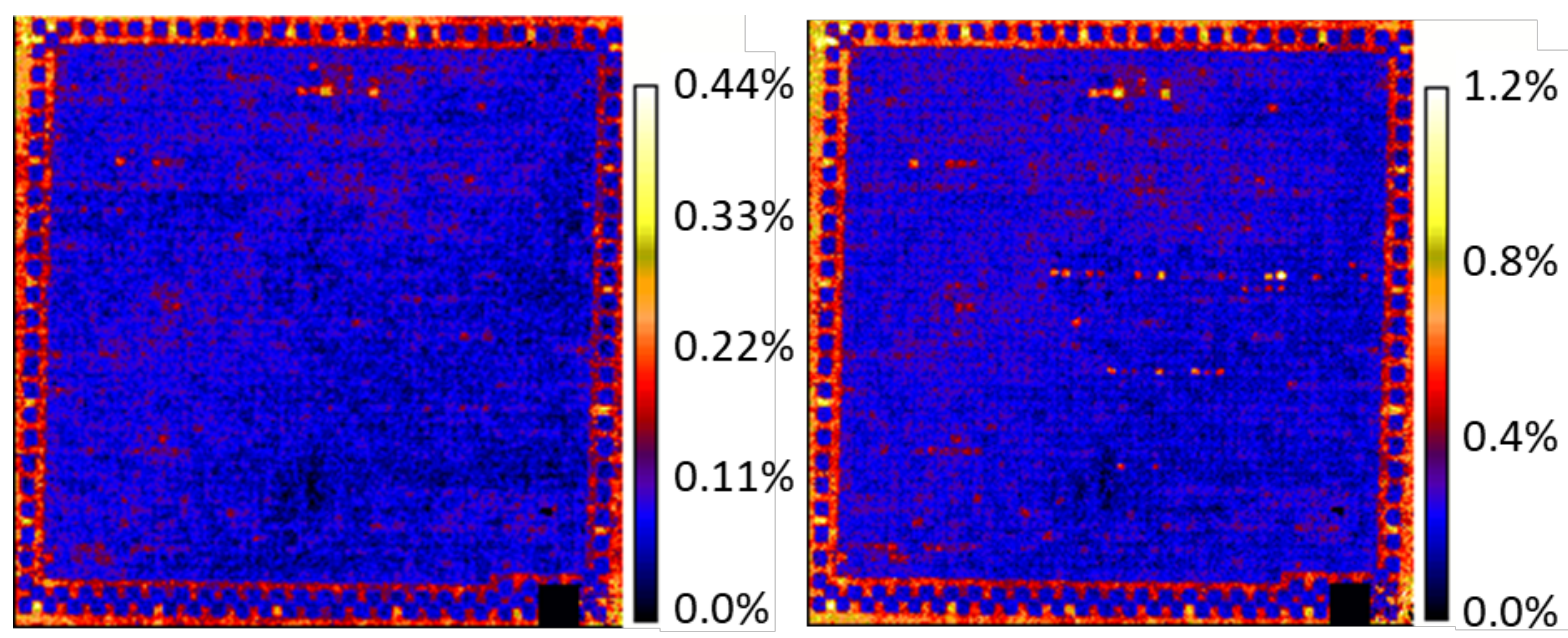

630 Figure S1. Chip-SIP isotope maps of a single phylogenetic microarray hybridized with

631 isotopically labeled RNA from a rhizosphere soil microbial community exposed to ${ }^{15} \mathrm{~N}-l a b e l e d$

632 root detritus and ${ }^{13} \mathrm{C}$-exudates. As the microbes consume the substrates with the different isotope

633 labels, they assimilate the isotopes into their microbial biomass and nucleic acids, and their

634 preference for the ${ }^{15} \mathrm{~N}$-root litter or ${ }^{13} \mathrm{C}$-exudates is determined by the amount of (A) ${ }^{15} \mathrm{~N}$ and (B)

$635{ }^{13} \mathrm{C}$ contained in the RNA hybridized to a probe set specific to each taxon. Color scale bars

636 indicate atom percent excess (APE) enrichment of the microarray surface. Probes sets are

637 arranged in horizontal lines on the chip. The brightest ${ }^{13} \mathrm{C}$-enriched probe sets with no visible

638 corresponding ${ }^{15} \mathrm{~N}$-enriched probes are from plant host RNA. 


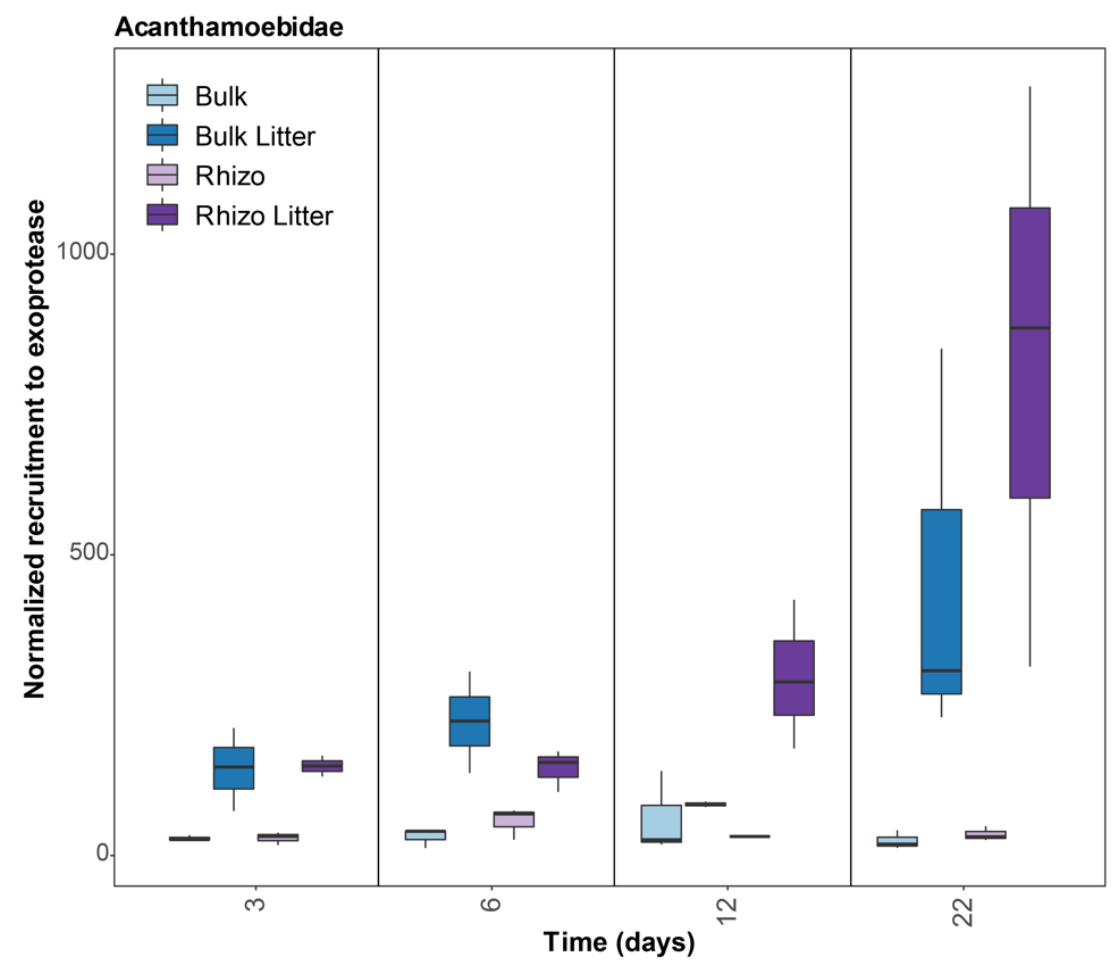

641 Figure S2. Acanthamoebidae exoprotease gene expression from a complimentary transcriptomic

642 dataset on the same soil (52) from 3-22 days. Rhizosphere and bulk soil were amended with

643 detrital root litter (Rhizo Litter, Bulk Litter) or unamended (Rhizo, Bulk). Sequences were

644 normalized using DESeq2 as previously (52).

645

646 


\section{REFERENCES}

648 1. Swift MJ, Anderson JM, Heal OW. Decomposition in terrestrial ecosystems. Oxford:

649 Blackwell Publishing; 1979 Jan 1.

650 2. Scholes MC, Powlson D, Tian G. Input control of organic matter dynamics. Geoderma

$651 \quad 1997 ; 79: 25-47$.

652 3. Greyston SJ, Vaughan D, Jones D. Rhizosphere carbon flow in trees, in comparison with 653 annual plants: the importance of root exudation and its impact on microbial activity and nutrient 654 availability. Applied Soil Ecology 1996; 5: 29-56.

655 4. Schimel DS. Terrestrial biogeochemical cycles: Global estimates with remote sensing. 656 Remote Sens Environ 1995; 51: 49-56.

657 5. Sokol NW, Kuebbing SE, Ayala EK, Bradford MA. Evidence for the primacy of living 658 root inputs, not root or shoot litter, in forming soil organic carbon. The New phytologist 2019;

659 221: 233-46.

660 6. Bardgett RD. The Biology of Soil: A Community Ecosystem Approach. Oxford: Oxford $661 \quad$ University Press; 2005.

662 7. Schimel JP, Schaeffer SM. Microbial control over carbon cycling in soil. Front Microbiol $663 \quad 2012 ; 3: 1-11$.

664 8. Geisen S, Mitchell EAD, Wilkinson DM, Adl S, Bonkowski M, Brown MW, et al. Soil 665 protistology rebooted: 30 fundamental questions to start with. Soil Biol Biochem 2017; 111: 94666103.

667 9. Sinsabaugh RL, Moorhead DL. Resource allocation to extracellular enzyme production: a 668 model for nitrogen and phosphorus control of litter decomposition. Soil Biol Biochem 1994; 26:

$669 \quad 1305-11$. 
670 10. Purahong W, Wubet T, Lentendu G, Schloter M, Pecyna MJ, Kapturska D, et al. Life in

671 leaf litter: novel insights into community dynamics of bacteria and fungi during litter

672 decomposition. Mol Ecol 2016; 25: 4059-74.

673 11. Osono T. Ecology of ligninolytic fungi associated with leaf litter decomposition. Ecol

$674 \quad$ Res 2007; 22: 955-74.

675 12. Hattenschwiler S, Tiunov AV, Scheu S. Biodiversity and litter decomposition in 676 terrestrial ecosystems. Annual Review Of Ecology Evolution And Systematics 2005; 36: 191-218.

677 13. Pugh G. Terrestrial Fungi. In: Dickenson C, Pugh G, editors. Biology of Plant Litter

678 Decomposition. 2. London: Academic Press Inc.; 1974. p. 303-36.

679 14. Geisen S, Koller R, Hünninghaus M, Dumack K, Urich T, Bonkowski M. The soil food 680 web revisited: Diverse and widespread mycophagous soil protists. Soil Biol Biochem 2016; 94 : $681 \quad 10-8$

682 15. Chakraborty S, Old K. Ultrastructure and description of a fungus-feeding amoeba, 683 Trichamoeba mycophaga n. sp. (Amoebidae, Amoebea), from Australia. J Eukaryot Microbiol $684 \quad 1986 ; 33: 564-9$.

685 16. Bjørnlund L, Rønn R. 'David and Goliath'of the soil food web-Flagellates that kill 686 nematodes. Soil Biol Biochem 2008; 40: 2032-9.

687 17. Xiong W, Jousset A, Guo S, Karlsson I, Zhao Q, Wu H, et al. Soil protist communities 688 form a dynamic hub in the soil microbiome. ISME J 2018; 12: 634-8.

689 18. Neher DA, Weicht TR, Barbercheck ME. Linking invertebrate communities to 690 decomposition rate and nitrogen availability in pine forest soils. Appl Soil Ecol 2012; 54: 14-23. 
691 19. Bokhorst S, Wardle DA. Microclimate within litter bags of different mesh size:

692 Implications for the 'arthropod effect' on litter decomposition. Soil Biol Biochem 2013; 58: 147-

69352.

694 20. Carrillo Y, Ball BA, Bradford MA, Jordan CF, Molina M. Soil fauna alter the effects of

695 litter composition on nitrogen cycling in a mineral soil. Soil Biol Biochem 2011; 43: 1440-9.

696 21. Riutta T, Slade EM, Bebber DP, Taylor ME, Malhi Y, Riordan P, et al. Experimental

697 evidence for the interacting effects of forest edge, moisture and soil macrofauna on leaf litter

698 decomposition. Soil Biol Biochem 2012; 49: 124-31.

699 22. Meyer WM, Ostertag R, Cowie RH. Macro-invertebrates accelerate litter decomposition

700 and nutrient release in a Hawaiian rainforest. Soil Biol Biochem 2011; 43: 206-11.

701 23. Stout JD. The Relationship between Protozoan Populations and Biological Activity in

702 Soils. Integr Comp Biol 1973; 13: 193-201.

703 24. Bonkowski M, Griffiths B, Scrimgeour C. Substrate heterogeneity and microfauna in soil

704 organic 'hotspots' as determinants of nitrogen capture and growth of ryegrass. Appl Soil Ecol

$705 \quad 2000 ; 14: 37-53$.

706 25. Tedersoo L, Anslan S. Towards PacBio-based pan-eukaryote metabarcoding using full-

707 length ITS sequences. Environmental Microbiology Reports 2019; 11: 659-68.

708 26. Tedersoo L, Anslan S, Bahram M, Põlme S, Riit T, Liiv I, et al. Shotgun metagenomes

709 and multiple primer pair-barcode combinations of amplicons reveal biases in metabarcoding

710 analyses of fungi. Mycokeys 2015; 10: 1-43.

711 27. Guillou L, Bachar D, Audic S, Bass D, Berney C, Bittner L, et al. The Protist Ribosomal

712 Reference database (PR2): a catalog of unicellular eukaryote Small Sub-Unit rRNA sequences

713 with curated taxonomy. Nucleic Acids Res 2013; 41: D597-D604. 
714 28. Baldrian P, Kolařík M, Štursová M, Kopecký J, Valášková V, Větrovský T, et al. Active

715 and total microbial communities in forest soil are largely different and highly stratified during

716 decomposition. ISME J 2012; 6: 248-58.

717 29. Poisot T, Péquin B, Gravel D. High-Throughput Sequencing: A Roadmap Toward

718 Community Ecology. Ecology and Evolution 2013; 3: 1125-39.

719 30. Nguyen NH, Smith D, Peay K, Kennedy P. Parsing ecological signal from noise in next

720 generation amplicon sequencing. New Phytol 2015; 205: 1389-93.

721 31. Engelbrektson A, Kunin V, Wrighton KC, Zvenigorodsky N, Chen F, Ochman H, et al.

722 Experimental factors affecting PCR-based estimates of microbial species richness and evenness.

723 ISME J 2010; 4: 642-7.

724 32. Suzuki MT, Giovannoni SJ. Bias caused by template annealing in the amplification of 725 mixtures of 16S rRNA genes by PCR. Appl Environ Microbiol 1996; 62: 625-30.

726 33. Soergel D, Dey N, Knight R, Brenner S. Selection of primers for optimal taxonomic

727 classification of environmental 16S rRNA gene sequences. ISME J 2012; 6: 1440-4.

728 34. Nomura M, Gourse R, Baughman G. Regulation of the synthesis of ribosomes and

729 ribosomal components. Annu Rev Biochem 1984; 53: 75-117.

730 35. Urich T, Lanzén A, Qi J, Huson DH, Schleper C, Schuster SC. Simultaneous assessment

731 of soil microbial community structure and function through analysis of the meta-transcriptome.

$732 \quad$ PLOS ONE 2008; 3: e2527.

733 36. Miller CS, Baker BJ, Thomas BC, Singer SW, Banfield JF. EMIRGE: reconstruction of

734 full-length ribosomal genes from microbial community short read sequencing data. Genome

735 biology 2011; 12: R44. 
736 37. Xue Y, Lanzén A, Jonassen I. Reconstructing ribosomal genes from large scale total

737 RNA meta-transcriptomic data. Bioinformatics 2020; 36: 3365-71.

738 38. Bang-Andreasen T, Anwar MZ, Lanzén A, Kjøller R, Rønn R, Ekelund F, et al. Total

739 RNA-sequencing reveals multi-level microbial community changes and functional responses to

740 wood ash application in agricultural and forest soil. FEMS Microbiol Ecol 2020; 96.

741 39. Geisen S, Tveit AT, Clark IM, Richter A, Svenning MM, Bonkowski M, et al.

742 Metatranscriptomic census of active protists in soils. ISME J 2015; 9: 2178-90.

743 40. Adl SM, Habura A, Eglit Y. Amplification primers of SSU rDNA for soil protists. Soil

744 Biol Biochem 2014; 69: 328-42.

745 41. Wagner M, P. H. Nielsen, A. Loy, J. L. Nielsen, and H. Daims. Linking microbial

746 community structure with function: fluorescence in situ hybridization-microautoradiography and

747 isotope arrays. . Curr Opin Biotechnol 2006; 17: 83-91.

748 42. Neufeld J, Wagner M, Murrell J. Who eats what, where and when? Isotope-labelling

749 experiments are coming of age. ISME J 2007; 1: 103-10.

750 43. Radajewski S, Ineson P, Parekh NR, Murrell J. Stable-isotope probing as a tool in

751 microbial ecology. Nature 2000; 403: 646-9.

752 44. Radajewski S, Murrell JC. Stable Isotope Probing for Detection of Methanotrophs After

753 Enrichment with 13CH4. In: de Muro MA, Rapley R, editors. Gene Probes: Principles and

754 Protocols. Totowa, NJ: Humana Press; 2002. p. 149-57.

755 45. Manefield M, Whiteley AS, Griffiths R, Bailey MJ. RNA Stable Isotope Probing, a

756 Novel Means of Linking Microbial Community Function to Phylogeny. Appl Environ Microbiol

7572002. 
758 46. Mayali X, Weber PK, Nuccio E, Lietard J, Somoza M, Blazewicz SJ, et al. Stable Isotope

759 Probing, Methods and Protocols. Methods in Molecular Biology 2019; 2046: 71-87.

760 47. Mayali X, Weber PK, Brodie EL, Mabery S, Hoeprich PD, Pett-Ridge J. High-throughput

761 isotopic analysis of RNA microarrays to quantify microbial resource use. ISME J 2012; 6: 1210-

2162

763 48. Waldrop MP, Firestone MK. Seasonal dynamics of microbial community composition

764 and function in oak canopy and open grassland soils. Microb Ecol 2006; 52: 470-9.

765 49. Shi S, Nuccio E, Herman DJ, Rijkers R, Estera K, Li J, et al. Successional Trajectories of

766 Rhizosphere Bacterial Communities over Consecutive Seasons. mBio 2015; 6: e00746.

767 50. DeAngelis KM, Brodie EL, DeSantis T, Andersen G, Lindow S, Firestone MK. Selective

768 progressive response of soil microbial community to wild oat. ISME J 2009; 3: 168-78.

769 51. Jaeger CH, Lindow SE, Miller W, Clark E, Firestone MK. Mapping of sugar and amino

770 acid availability in soil around roots with bacterial sensors of sucrose and tryptophan. Appl

771 Environ Microbiol 1999; 65: 2685-90.

772 52. Nuccio EE, Starr E, Karaoz U, Brodie EL, Zhou J, Tringe SG, et al. Niche differentiation

773 is spatially and temporally regulated in the rhizosphere. ISME J 2020; 269: 1-16.

774 53. Griffiths RI, Whiteley AS, O'Donnell AG, Bailey M. Rapid method for coextraction of

775 DNA and RNA from natural environments for analysis of ribosomal DNA- and rRNA-based

776 microbial community composition. Appl Environ Microbiol 2000; 66: 5488-91.

777 54. Andrews S. FastQC: A Quality Control tool for High Throughput Sequence Data

778 (Version 0.10.1) 2012; http://www.bioinformatics.babraham.ac.uk/projects/fastqc/

779 55. Bolger AM, Lohse M, Usadel B. Trimmomatic: a flexible trimmer for Illumina sequence

780 data. Bioinformatics 2014; 30: 2114-20. 

improved Greengenes taxonomy with explicit ranks for ecological and evolutionary analyses of

783 bacteria and archaea. ISME J 2012; 6: 610-8.

784 57. Quast C, Pruesse E, Yilmaz P, Gerken J, Schweer T, Yarza P, et al. The SILVA

785 ribosomal RNA gene database project: improved data processing and web-based tools. Nucleic

786 Acids Res 2013; 41: D590-D6.

787 58. Langmead B, Trapnell C, Pop M, Salzberg SL. Ultrafast and memory-efficient alignment 788 of short DNA sequences to the human genome. Genome biology 2009; 10: R25.

789 59. Edgar RC. UPARSE: highly accurate OTU sequences from microbial amplicon reads.

$790 \quad$ Nat Methods 2013; 10: $996-8$.

791 60. Caporaso JG, Kuczynski J, Stombaugh J, Bittinger K, Bushman FD, Costello EK, et al. 792 QIIME allows analysis of high-throughput community sequencing data. Nat Methods 2010; 7: $793 \quad 335-6$.

794 61. Wang Q, Garrity GM, Tiedje JM, Cole JR. Naive Bayesian classifier for rapid 795 assignment of rRNA sequences into the new bacterial taxonomy. Appl Environ Microbiol 2007;

$796 \quad 73: 5261-7$.

797 62. Edgar RC, Haas BJ, Clemente JC, Quince C, Knight R. UCHIME improves sensitivity 798 and speed of chimera detection. Bioinformatics 2011; 27: 2194-200.

799 63. Miller CS, Handley KM, Wrighton KC, Frischkorn KR, Thomas BC, Banfield JF. Short800 read assembly of full-length $16 \mathrm{~S}$ amplicons reveals bacterial diversity in subsurface sediments.

$801 \quad$ PLOS ONE 2013; 8: e56018.

802 64. Lozupone C, Knight R. UniFrac: a new phylogenetic method for comparing microbial 803 communities. Appl Environ Microbiol 2005; 71: 8228-35. 
804 65. Ludwig W, Strunk O, Westram R, Richter L, Meier H, Yadhukumar, et al. ARB: a

805 software environment for sequence data. Nucleic Acids Res 2004; 32: 1363-71.

806 66. Mayali X, Weber PK, Pett-Ridge J. Taxon-specific C/N relative use efficiency for amino

807 acids in an estuarine community. FEMS Microbiol Ecol 2013; 83: 402-12.

808 67. de Ruiter PC, Neutel AM, Moore JC. Energetics, patterns of interaction strengths, and

809 stability in real ecosystems. Science 1995; 269: 1257-60.

810 68. Glücksman E, Bell T, Griffiths RI, Bass D. Closely related protist strains have different

811 grazing impacts on natural bacterial communities. Environ Microbiol 2010; 12: 3105-13.

812 69. Yeates GW, Bongers T, De Goede R, Freckman DW, Georgieva SS. Feeding habits in

813 soil nematode families and genera - an outline for soil ecologists. J Nematol 1993; 25: 315-31.

814 70. Griffiths BS. Microbial-feeding nematodes and protozoa in soil: Their effectson

815 microbial activity and nitrogen mineralization in decomposition hotspots and the rhizosphere.

$816 \quad$ Plant Soil 1994; 164: 25-33.

817 71. Bonkowski M, Clarholm M. Stimulation of plant growth through interactions of bacteria

818 and protozoa: testing the auxiliary microbial loop hypothesis. Acta Protozool 2012; 51: 237-47.

819 72. Clarholm M. Interactions of bacteria, protozoa and plants leading to mineralization of soil

820 nitrogen. Soil Biol Biochem 1985; 17: 181-7.

821 73. Gao Z, Karlsson I, Geisen S, Kowalchuk G, Jousset A. Protists: Puppet Masters of the

822 Rhizosphere Microbiome. Trends Plant Sci 2019; 24: 165-76.

823 74. Bates ST, Clemente JC, Flores GE, Walters WA, Parfrey LW, Knight R, et al. Global

824 biogeography of highly diverse protistan communities in soil. ISME J 2013; 7: 652-9.

825 75. el Zahar Haichar F, Achouak W, Christen R. Identification of cellulolytic bacteria in soil

826 by stable isotope probing. Environ Microbiol 2007; 9: 625-34. 
827 76. Lee CG, Watanabe T, Sato Y, Murase J, Asakawa S, Kimura M. Bacterial populations

828 assimilating carbon from 13C-labeled plant residue in soil: Analysis by a DNA-SIP approach.

829 Soil Biol Biochem 2011; 43: 814-22.

830 77. Eichorst SA, Kuske CR. Identification of cellulose-responsive bacterial and fungal

831 communities in geographically and edaphically different soils by using stable isotope probing.

832 Appl Environ Microbiol 2012; 78: 2316-27.

833 78. Okada H, Harada H, Kadota I. Fungal-feeding habits of six nematode isolates in the

834 genus Filenchus. Soil Biol Biochem 2005; 37: 1113-20.

835 79. Rotem O, Pasternak Z, Jurkevitch E. Bdellovibrio and Like Organisms. In: Rosenberg E,

836 DeLong EF, Lory S, Stackebrandt E, Thompson F, editors. The Prokaryotes, Deltaproteobacteria

837 and Epsilonproteobacteria. Berlin: Springer-Verlag; 2014. p. 3-17.

838 80. Leveau JHJ, Uroz S, Boer WD. The bacterial genus Collimonas: mycophagy, weathering

839 and other adaptive solutions to life in oligotrophic soil environments. Environ Microbiol 2010;

$840 \quad$ 12: $281-92$

841 81. Cotrufo MF, Wallenstein MD, Boot CM, Denef K, Paul E. The Microbial Efficiency-

842 Matrix Stabilization (MEMS) framework integrates plant litter decomposition with soil organic

843 matter stabilization: do labile plant inputs form stable soil organic matter? Global Change Biol

$844 \quad 2013 ; 19: 988-95$.

845 82. Wickings K, Grandy AS, Reed SC, Cleveland CC. The origin of litter chemical

846 complexity during decomposition. Ecol Lett 2012; 15: 1180-8.

847 83. Schmidt MWI, Torn MS, Abiven S, Dittmar T, Guggenberger G, Janssens IA, et al.

848 Persistence of soil organic matter as an ecosystem property. Nature 2011; 478: 49-56. 
849 84. Allison SD, Martiny JB. Resistance, resilience, and redundancy in microbial

850 communities. Proc Natl Acad Sci USA 2008; 105: 11512-9.

851 85. Sutton R, Sposito G. Molecular structure in soil humic substances: The new view.

852 Environmental Science \& Technology 2005; 39: 9009-15.

853 86. Kleber M, Sollins P, Sutton R. A conceptual model of organo-mineral interactions in

854 soils: self-assembly of organic molecular fragments into zonal structures on mineral surfaces.

855 Biogeochemistry 2007; 85: 9-24.

856 87. Kögel-Knabner I. The macromolecular organic composition of plant and microbial

857 residues as inputs to soil organic matter. Soil Biol Biochem 2002; 34: 139-62.

858 88. Amelung W, Brodowski S, Sandhage-Hofmann A, Bol R. Combining biomarker with

859 stable isotope analyses for assessing the transformation and turnover of soil organic matter.

860 Advances in agronomy 2008; 100: 155-250.

861 89. Halter D, Goulhen-Chollet F, Gallien S, Casiot C, Hamelin J, Gilard F, et al. In situ

862 proteo-metabolomics reveals metabolite secretion by the acid mine drainage bio-indicator,

863 Euglena mutabilis. ISME J 2012; 6: 1391-402.

864 90. Wright ES, Yilmaz LS, Noguera DR. DECIPHER, a search-based approach to chimera

865 identification for 16S rRNA sequences. Appl Environ Microbiol 2012; 78: 717-25.

866 91. Haas BJ, Gevers D, Earl AM, Feldgarden M, Ward DV, Giannoukos G, et al. Chimeric

867 16S rRNA sequence formation and detection in Sanger and 454-pyrosequenced PCR amplicons.

868 Genome Res 2011; 21: 494-504.

869 92. Pett-Ridge J, Hoeprich P, Weber P, Brodie E, inventors; Lawrence Livermore National

870 Security, assignee. Devices, Methods and Systems for Target Detection. USA2011. 
bioRxiv preprint doi: https://doi.org/10.1101/2021.01.12.426429; this version posted January 13,2021 . The copyright holder for this preprint

(which was not certified by peer review) is the author/funder. This article is a US Government work. It is not subject to copyright under 17 USC 105 and is also made available for use under a CCO license.

871 93. Singh-Gasson S, Green RD, Yue Y, Nelson C, Blattner F, Sussman MR, et al. Maskless

872 fabrication of light-directed oligonucleotide microarrays using a digital micromirror array. Nat

873 Biotechnol 1999; 17: 974-8.

874 